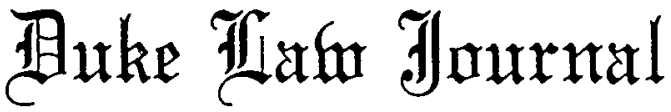

\section{LEAGUE CONTROL OF MARKET OPPORTUNITIES: A PERSPECTIVE ON COMPETITION AND COOPERATION IN THE SPORTS INDUSTRY}

\author{
JOHN C. WEISTART*
}

\begin{abstract}
An issue unsettled for at least the past decade is the proper characterization of a professional sports league for antitrust purposes. Recent litigation over the efforts of the National Football League to block the move by the Raiders from Oakland to Los Angeles should have been the occasion for a significant judicial clarification. The Ninth Circuit decision in the case seeks to limit league discretion and give individual clubs the right to pursue their separate entrepreneurial advantage. When subjected to close examination, however, the decision appears to be premised on themes that are fundamentally inconsistent. The present article suggests that a more coherent view of the antitrust issues in league governance requires that greater weight be given to the corporate nature of the league's enterprise. An outcome sensitive to this characteristic is more apt to satisfy the basic antitrust policy of enhancing consumer welfare. Other antitrust and public policy questions remain, but their resolution should not proceed from a conspiratorial view of league governance.
\end{abstract}

\section{INTRODUCTION}

A. The Insider-Outsider Paradox.

Assume that we are back at a point in time when there is only one National Football League (NFL) team in Los Angeles. Assume that it has become clear that the Los Angeles area could support a second football franchise. Assume further that no existing franchise has expressed an interest in moving into the market. If a prospective owner from outside the NFL approached the league and were otherwise approved for

(C) 1984 John C. Weistart

- Professor of Law, Duke University 
the franchise, could the league make the new owner pay a substantial fee for the opportunity to operate in Los Angeles? Surely the answer is yes. The league in effect would be giving up a valuable asset, an asset that was produced as a result of the efforts of the league's co-venturers. Because the league has nurtured itself carefully-pursuing sound broadcasting, franchising, and product development practices-an NFL franchise has considerable value. And it should be carefully noted that it is not simply professional football that is so popular, but rather the version offered by this particular league, the NFL. ${ }^{1}$ The league would be transferring an important asset of an unmistakable proprietary character, and it should be able to expect a fair price in exchange. The value of the Los Angeles franchise in the present market is speculative, but a fee of $\$ 30-\$ 45$ million could probably be defended.2

Now change one assumption. Assume that the club seeking the second Los Angeles franchise is not an outsider, but rather an existing club within the NFL. Can the league impose a similar multimillion dollar charge for the valuable right that is relinquished? The Oakland Raiders case-officially captioned Los Angeles Memorial Coliseum Commission v. National Football League ${ }^{3}$-seems to say "no." This case suggests that an exquisite corporate opportunity-an excellent NFL franchise location-can be claimed at no cost by an existing league member. Thus, an asset which can be sold for a considerable amount to someone on the outside must be given away to an insider. The general justification for this result is not readily apparent. And if one looks to the antitrust laws for an explanation, the paradox is more acute, for it is far from obvious

1. There are, of course, other versions of professional football. The United States Football League (USFL) presently offers one. In recent memory, the World Football League offered another. There should be little debate that these other leagues have offered an "opportunity" of a different magnitude than that available in the NFL. Understandably, then, the value of an NFL franchise is higher than the alternatives that have recently been available.

2. Reported prices for recent franchise sales include approximately $\$ 70$ million for the Denver Broncos in 1984, Sports Indus. News, Mar. 28, 1984, at 56, and approximately $\$ 60$ million for the Dallas Cowboys in 1984. Id. See also Guth, Investing in a Pro Team: Expensive, Bul Worth It, N.Y. Times, July 6, 1980, $\$ 5$, at 2 , col. 1 (estimating value of Giants and Jets at $\$ 59$ million and $\$ 57$ million respectively); N.Y. Times, Sept. 22, 1982, at B20, col. 2 (Leonard Tose settles suit arising from his June 17, 1983 agreement to sell $99 \%$ interest in Philadelphia Eagles for $\$ 42$ million). The figure used in the text is lower than those mentioned here because an established team includes assets other than the franchise location. On the other hand, a new franchise would be entitled to valuable rights, including the right to receive more than $\$ 10$ million a year under the league's television contract.

3. 726 F.2d 1381 (9th Cir. 1984), cert. denied, 105 S. Ct. 397 (1984). See also Los Angeles Memorial Coliseum Comm'n v. National Football League, 484 F. Supp. 1274 (C.D. Cal.), rev'd and remanded, 634 F.2d 1197 (9th Cir. 1980); Los Angeles Memorial Coliseum Comm'n v. National Football League, 468 F. Supp. 154 (C.D. Cal. 1979). 
how the goals of the antitrust laws-increased competition and increased consumer choice-are promoted in the one instance but not the other.

This example suggests but one of the several fundamental uncertainties that remain after the Ninth Circuit's decision in Los Angeles Coliseum. The case arose in the wake of the controversy prompted by $\mathrm{Al}$ Davis' effort to move his Oakland Raiders franchise to Los Angeles. ${ }^{4}$ The league initially blocked the move under a rule in its constitution, Rule 4.3, which required approval by fellow owners before one club could invade another's franchise territory-in this case the territory allocated to the Los Angeles Rams. ${ }^{5}$ The Raiders and the Los Angeles Coliseum Commission, which stood to gain Davis' team as a tenant, sued, alleging among other things that the league action violated section 1 of the Sherman Act. ${ }^{6}$ The claim was upheld in the district court, and in a 2 -

4. Background information on the controversy can be found in the following selected sources, listed here in chronological order: N.Y. Times, Jan. 19, 1980, at 17, col. 6 (Davis announces move); Washington Post, Feb. 27, 1980, at D2, col. 1 (Commissioner Rozelle expresses "fear of anarchy"); id., Mar. 11, 1980, at D3, col. 3 (five-member NFL fact-finding committee reports to other owners); L.A. Times, May 3, 1980, Pt. III, at 1, col. 1 (summary of developments); Nack \& Sullivan, Football's Little Bighorn?, SPORTS IlLUS., Jan. 26, 1981, at 32, 32 (Rozelle and Davis exchange charges over alleged ticket-scalping by owners); N.Y. Ti L $_{21}$ es, Apr. 26, 1982, $\S 5$, at 7, col. 1 (rumors of settlement that would keep Raiders in Oakland and give Davis interest in new franchise in Los Angeles); Washington Post, May 20, 1981, at Dl, col. 4 (first trial begins); N.Y. Times, May 27, 1981, at B8, col. 1 (testimony of Commissioner Rozelle); id., June 21, 1981, §5, at 5, col. 3 (testimony of Al Davis); Granelli, The Antitrust Super Bowl, NAT'L L.J., June 29, 1981, at 1, col. 2 (summary of legal arguments); N.Y. Times, July 28, 1981, at C13, col. 1 (case sent to jury); id., Aug. 15, 1981, at 17, col. 2 (hung jury; mistrial declared; Davis says one juror who held out was a NFL "plant"); id., Aug. 29, 1981, at 22, col. I (NFL and City of Los Angeles discuss possibility of new team); $i d$., Mar. 30, 1982, at C12, col. 3 (second trial begins); id., May 9, 1982, §5, at 1, col. 3 (discussion of jury verdict in favor of plaintifts); L.A. Times, July 9, 1982, Pt. III, at 1, col. 1 (analysis of Raiders' agreement with Coliseum); id., July 12, 1982, Pt. III, at 1, col. 1 (discussion of $\$ 6.7$ million non-recourse loan by Coliseum to Davis); N.Y. Times, Mar. 15, 1983, at B8, col. 4 (damage phase of litigation begins); id., Apr. 14, 1983, at B17, col. 5 (jury awards more than $\$ 16$ million damages to plaintiffs; trebled to more than $\$ 49$ million); id., May 3, 1983, at B8, col. 5 (Raiders file new suit against NFL charging obstruction of justice; seeking additional damages of more than $\$ 50$ million); id., Sept. 14, 1983, at B11, col. 4 (court dismisses several counts of obstruction of justice suit). See also infra note 6.

5. Rule 4.3 originally required unanimous approval of all twenty-eight NFL teams before a club could relocate into the home territory of another club. After an initial unsuccessful suit by the Coliseum Commission, Los Angeles Memorial Coliseum Comm'n v. National Football League, 468 F. Supp. 154 (C.D. Cal. 1979), the NFL amended Rule 4.3 to lower the voting requirement. Following the change, a move into another club's territory would be approved only if three-fourths of the teams voted to approve it. When the issue of the Raiders' move into the Rams' territory was put to a vote, no clubs voted in favor of it, twenty-two voted against it, and five abstained. See Los Angeles Coliseum, 726 F.2d at 1385.

6. Sherman Act, $\S 1$, ch. 647,26 Stat. 209, 209 (1890) (codified as amended at 15 U.S.C. $\S 1$ (1982)). The controversy surrounding the Raiders' move was not confined to the present antitrust action. The City of Oakland attempted to condemn the franchise under its power of eminent domain. That effort, initially unsuccessful, raised a number of legal issues, including whether intangible rights were subject to condemnation and whether a condemnation action against a sports 


\section{1 decision, the Ninth Circuit affirmed.7}

The decision of the Ninth Circuit has significant implications on several levels. It of course purports to answer the important immediate question: can the league control the relocation of its franchises? Beyond that, though, the decision invites the use of the antitrust laws in judicial oversight of internal league relationships. The decision will have a good deal of relevance for the general question of a league's authority to control the conduct of its members. ${ }^{8}$ Prior to Los Angeles Coliseum, leagues operated on the assumption that most matters of economic significance were potentially subject to the joint control of league members, either by direct vote or through the league commissioners. ${ }^{9}$ The majority opinion in Los Angeles Coliseum can be seen as an initial judicial effort to prompt a reexamination of that premise. While many league decisions will be protected by the rule of reason, the majority's decision-if upheld-will broaden the economic freedom of individual clubs.

It is doubtful, however, whether the majority opinion in Los Angeles Coliseum presents a coherent view of the limits that exist on the right of clubs within a league to control the behavior of their co-venturers. A close review of the majority's analysis reveals fundamental conceptual

franchise was sufficiently imbued with a public purpose. See City of Oakland v. Oakland Raiders, 32 Cal. 3d 60, 64, 183 Cal. Rptr. 673, 676, 646 P.2d 835, 838, vacating 123 Cal. App. 3d 422, 176 Cal. Rptr. 646 (1981); Note, Public Use in Eminent Domain: Are There Limits After Oakland Raiders and Poletown?, 20 CAL. W.L. REV. 82, 108 (1983) (criticizing failure of California Supreme Court to set limits on eminent domain power); Note, Taking the Oakland Raiders: A Theoretical Reconsideration of the Concepts of Public Use and Just Compensation, 32 EMORY L.J. 857, 887-89 (1983); Note, Eminent Domain Exercised-Stare Decisis or a Warning: City of Oakland v. Oakland Raiders, 4 PACE L. Rev. 169, 192-93 (1983); Note, City of Oakland v. Oakland Raiders: Defining the Parameters of Limitless Power, 1983 UTAH L. REV. 397, 403; Note, California Eminent Domain Statute Allows the Taking of Any Type of Property Interests - City of Oakland v. Oakland Raiders, 6 WHITTIER L. REV. 135, 138 (1984).

In a 1984 rehearing in the case, an additional issue was raised. A Monterey County Superior judge again ruled against the City of Oakland, finding that local condemnation of a sports franchise would unreasonably burden interstate commerce and was thus unconstitutional. See Sports Indus. News, Aug. 1, 1984, at 128.

7. 726 F.2d 1381 (9th Cir. 1984), affg 519 F. Supp. 581 (C.D. Cal. 1981). As noted, the issue of damages was determined in a later trial. The jury's award of damages, when trebled, amounted to more than $\$ 49$ million. See supra note 4.

8. A persistent rumor accompanying the Raiders' controversy suggested that Al Davis, the Raiders' owner, would seek to use the precedent of the case to claim for himself any revenues that might be generated by local cable or pay-cable television rights. See Antitrust Policy and Professional Sports: Hearings on H.R. 823, H.R. 3287, and H.R. 6467 Before the Subcomm. on Monopolies and Commercial Law of the House Comm. on the Judiciary, 97th Cong., 1st \& 2d Sess. 590 (1981-82) (testimony of Edward Garvey, Exec. Dir. National Football League Players Association); id. at 63132 (statement of Daniel M. Rooney, owner, Pittsburgh Steelers) [hereinafter cited as Heariugs]. Such a move, especially if followed by other clubs, could have a significant impact on the value of the league's network television contract.

9. See infra notes $35-41$ and accompanying text. 
tensions. Indeed, there is much to suggest that the majority never is able to present an adequate explanation of how the inherently cooperative nature of a league venture is to be reconciled with the court's apparent desire to promote competition among league clubs. A search for alternative grounds for accommodating the need for intraleague cooperation provides a basis for suggesting that the majority's condemnation of the league's franchise controls may not be correct.

\section{B. Background of the Los Angeles Coliseum Litigation.}

The legal theory of Los Angeles Coliseum rests on section 1 of the Sherman Act. The section proscribes concerted action that restrains competitive opportunities. ${ }^{10}$ There are three relevant antitrust issues in the Raiders' controversy:

1. Should the league be treated as a single entity incapable of violating section 1 ?

2. If the league's actions are within section 1 , are its rules so inherently anticompetitive as to be subject to per se condemnation, or is the more deliberative approach of the rule of reason appropriate?

3. If the league's control of franchise moves are to be judged under the rule of reason, what is the relative balance between the anticompetitive effects of the restraint and any procompetitive justifications that might be offered for them?

By the time the district court's finding of liability reached the Ninth Circuit, only the first and third issues remained in controversy. Earlier proceedings had settled the point that the special characteristics of a sports league made a summary condemnation under the per se rule inappropriate. ${ }^{11}$

Underlying the first issue is the defendants' contention that the relevant "firm" for section 1 purposes is the league and not the individual clubs that comprise it. ${ }^{12}$ Section 1 requires a duality of action before it is

10. The pertinent language of section 1 provides that "[e]very contract, combination in the form of trust or otherwise, or conspiracy, in restraint of trade or commerce . . . is declared to be illegal." Shernian Act, $\S 1$, ch. 647, 26 Stat. 209, 209 (1890) (codified as amended at 15 U.S.C. $\S 1$ (1982)).

11. See Los Angeles Memorial Coliseum Comm'n v. National Football League, 484 F. Supp. 1274 (C.D. Cal.), rev'd on other grounds \& remanded, 634 F.2d 1197 (9th Cir. 1980). The correctness of the choice in favor of the rule of reason approach seems to have been confirmed in the Supreme Court's subsequent decision in NCAA v. Board of Regents, 104 S. Ct. 2948 (1984). There the Court seems to create an industry-wide rule that removes the activities of sports associations and leagues from the purview of the summary per se approach. The inherent need for internal agreement and coordination is given as the reason. See id. at 2961.

12. See generally J. Weistart \& C. Lowell, The Law of SporTs 692-93, 698-701 (1979). 
violated. Only concerted action is condemned. ${ }^{13}$ Internal decisionmaking by a single firm is not encompassed by this section, but is left to be scrutinized under other antitrust provisions, particularly section 2 of the Sherman Act which proscribes monopolization. ${ }^{14}$ The defendants contended in this case, and in others, ${ }^{15}$ that the economic interdependence of the league clubs and the agreed-upon procedures for joint control gave the league the status of a single entity. The league clubs emphasized that some ninety percent of revenues were shared among the league's members. ${ }^{16}$ In addition, the defendants argued that an important goal of the league was to insure that member clubs were relatively balanced in terms of their competitiveness on the athletic field. Dominance by one or few clubs would substantially diminish the value of the clubs' television offering and reduce fan interest in live attendance. ${ }^{17}$ This need for balance in the clubs' athletic product was said to warrant an array of equalizing controls that rendered the league an essentially cooperative venture. ${ }^{18}$

13. See E. Gellhorn, ANTitrust Law and Economics 19-72 (1981); L. Sullivan, HandBOOK OF THE LAW OF ANTITRUST § 108 (1977).

14. See Copperweld Corp. v. Independence Tube Corp., 104 S. Ct. 2731, 2742-44 (1984). See also Areeda, Intraenterprise Conspiracy in Decline, 97 HARV. L. REv. 451 (1983).

15. See Mid-South Grizzlies v. National Football League, 550 F. Supp. 558, 562 (E.D. Pa. 1982), affd, 720 F.2d 772 (3d Cir. 1983); North American Soccer League v. National Football League, 505 F. Supp. 659, 671-72 (S.D.N.Y. 1980), aff'd in part \& rev'd in part, 670 F.2d 1249 (2d Cir. 1982). See also San Francisco Seals, Ltd. v. National Hockey League, 379 F. Supp. 966, $969-70$ (C.D. Cal. 1974).

16. See Los Angeles Coliseum, 762 F.2d at 1390.

17. A point that has never been substantially disputed, even by critics of league practices, is that the success of a league requires that clubs field teams that are relatively evenly matched in terms of their playing ability. See Quirk \& El Horidi, The Economic Theory of a Professional Sports League in Government and the Sports Business 33, 34-37 (R. Noll ed. 1974); Glick, Professional Sports Franchise Movements and the Sherman Act: When and Where Teams Should Be Able to Move, 23 Santa Clara L. Rev. 55, 67 (1983); Kempf, The Misapplication of Antitrust Law to Professional Sports Leagues, 32 DE PAUL L. REv. 625, 628 (1983); Rottenberg, The Baseball Player's Labor Market, 64 J. PoL. EcoN. 242, 254 (1956); Comment, The Super Bowl and the Sherman Act: Professional Team Sports and the Antitrust Laws, 81 HARV. L. REV. 418, 421 (1967); Comment, Application of Antitrust Laws to Professional Sports' Eligibility and Draft Rules, 46 MO. L. REV. 797, 826 (1981). The need for high quality, balanced competition is confirmed by a review of attendance statistics. As most sports fans know, a good team playing another good team will draw more fans than a contest in which a weak team is matched against either a good team or another weak team. See H. Demmert, The Economics of Professional Team Sports 11 (1973) (statistical sample showing a correlation between paid attendance at a particular game and the quality of the teams involved).

18. The need for on-the-field competitive balance has been asserted as the justification for a variety of league practices ranging from franchise controis to the draft system and other player restraints. Although critical of the particular restraints under review, the most authoritative decision examining the antitrust implications of league controls on player mobility has agreed with the essential point that leagues may properiy take steps to equalize the athletic competition that occurs among clubs. See Mackey v. National Football League, 543 F.2d 606, 621-22 (8th Cir. 1976). See also Smith v. Pro Football, Inc., 593 F.2d 1173, 1187 (D.C. Cir. 1978) ("We do not foreclose the 
Thus, in the clubs' view, the league was much like a partnership or corporation, and its actions were not of the sort to which section 1 was addressed. ${ }^{19}$

The third issue assumes that the league is subject to section 1 and must thus confront a substantive application of the rule of reason. Courts have long conceded that the language of section 1 condemning "every" agreement in restraint of trade cannot be applied literally. ${ }^{20}$ Rather, a rule of reason is used to identify those actions that have some restraining effect but that will nonetheless be upheld. The meaning of the rule of reason has been the subject of considerable uncertainty over the years. For some, the name seems to invite arguments that the restriction in question is drawn in a "reasonable" or temperate fashion. In recent cases, however, the Supreme Court has made a concerted effort to clarify the content of the rule and specifically to dispel the notion that only temperance and reasonableness in the construction of a restraint are required. The Court on several occasions since 1978 has emphasized that the focus of the rule of reason should be on the competitive conditions in the relevant market. ${ }^{21}$ The market must, on balance, be rendered more competitive as a result of the particular restraint if it is to be upheld. Restrictions that limit competition must have a strong, countervailing procompetitive justification to be sustained. ${ }^{22}$ And a recent case has revealed that the Supreme Court is prepared to view enhancement of the

possibility that some type of player selection system might be defended as serving "to regulate and promote . . . competition' in the market for players' services.").

19. For a more elaborate discussion of the analogy between a partnership and a sports league as it applies to franchise location, see J. WEISTART \& C. LowELL, supra note 12, at 699-702. A further refinement of the analogy is set forth in a subsequent segment of this article. See infra notes 111-33 and accompanying text.

20. See Chicago Bd. of Trade v. United States, 246 U.S. 231, 238 (1918) (employing a rule of reason analysis); Standard Oil Co. v. United States, 221 U.S. 1, 60 (1911) ("it was intended that the standard of reason . . . be the measure used for the purpose of determining whether in a given case a particular act had or had not brought about the wrong against which [Section 1] provided").

21. See NCAA v. Board of Regents, 104 S. Ct. 2948, 2962 (1984); Broadcast Music, Inc. v. CBS, 441 U.S. 1, 19-20 (1979); National Soc'y of Professional Eng'rs v. United States, 435 U.S. 679, 688 (1978).

22. Most courts view the rule of reason after National Soc'y of Professional Eng'rs v. United States, 435 U.S. 679, 688 (1978) as requiring an analysis in which the anticompetitive effects of a restraint are assessed in light of the procompetitive justifications that are put forth. See, e.g., Cascade Cabinet Co. v. Western Cabinet \& Millwork, Inc., 710 F.2d 1366, 1373 (9th Cir. 1983); Smith v. Pro Football, Inc., 593 F.2d 1173, 1186 (D.C. Cir. 1978). This was also the approach endorsed in the instant case. See Los Angeles Coliseum, 726 F.2d at 1390-92. For further views on the nature of the analysis called for under the rule of reason, see P. AREEDA, THE "RuLE OF REASON" IN ANT1TRUST ANALySIS: GeNERAL Issues (Federal Judicial Center 1981); Flynn, Rethinking Sherman Act Section I Analysis: Three Proposals for Reducing the Chaos, 49 ANTITRUST L.J. 1593 (1980); Memorandum of Arnold \& Porter to Commissioner of Baseball Re: Problem That Would Arise in Applying the Rule of Reason to Baseball's Practices and Institutions (Feb. 22, 1982), reprinted in Hearings, supra note 8, at 439-45. 
competitiveness of a cooperative enterprise vis-a-vis other competitors as procompetitive. ${ }^{23}$

The defendants offered several justifications for franchise controls in Los Angeles Coliseum. In addition to suggesting that the controls were merely ancillary to the main venture of producing a league version of professional football, the defendants contended that the restraints helped achieve market penetration and regional balance. ${ }^{24}$ The league also contended that the controls promoted financial stability among franchises, and that they encouraged fan loyalty and the cooperation of local governments. 25

As the outcome of the appellate decision suggests, the league lost on both its single entity defense and its efforts to secure a favorable review under the rule of reason. The critical aspects of the Ninth Circuit's rationale are examined in considerable detail below. ${ }^{26}$ As will be noted, the court rejected the single entity argument on the grounds that the individual clubs maintained sufficiently distinct identities to preserve their separate relevance for antitrust purposes. Thus an agreement between the clubs to disapprove the Raiders' move had the requisite duality. ${ }^{27}$ The court believed that this conclusion was supported by the fact that clubs retained ultimate control of management decisions and ultimate responsibility for profits and losses. The court also feared that recognition of the single entity defense would exempt the league from antitrust scrutiny for a wide variety of its activities. Existing case precedent, in the court's view, supported a refutation of such an exemption.

On the merits of the league's franchise controls, the court accepted that the league's concerns for regional balance, financial stability, and community support were cognizable justifications under the rule of reason. It concluded, however, that as applied to the Raiders Rule 4.3 swept too broadly. In the view of the majority, the league had available less restrictive alternatives for protecting its interests. ${ }^{28}$ Rather than using a general vote to review the proposed franchise move, the league, in the court's view, should have used an objective standard that considered such questions as the adequacy of the population base in the new city, the

23. See NCAA v. Board of Regents, 104 S. Ct. 2948, 2961 (1984) (NCAA plays a vital role in preserving distinctive nature of college football, widening consumer choice, and hence its aetions can be viewed as procompetitive); see also Broadcast Music, Inc. v. CBS, 441 U.S. 1, 18-23 (1979) (holding that a joint selling arrangement may be so efficient that it will increase seller's aggregate output and thus be procompetitive).

24. See Los Angeles Coliseum, 726 F.2d at 1396.

25. Id.

26. See infra notes 33-66 and accompanying text.

27. Los Angeles Coliseum, 726 F.2d at 1387-90.

28. Id. at 1396-97. 
suitability of the proposed stadium, and the effect of the move on the marketability of the league games on television. Because the league's disapproval could not be shown to have been based on such considerations, it was rejected and the Raiders' franchise was permitted to move. ${ }^{29}$

29. Under the approach used by the majority, the court announces a legal standard that it does not have to apply. Because its proposed objective standards were not even considered by the league-or at least not explicitly so-the court believes that it can conclude that the league's decision was improper. It is thus left to subsequent cases to determine whether the tests put forth are workable and realistic.

One troublesome feature of the court's approach is the remedy that it affords to the particular plaintiffs in this case. The Raiders are allowed to move without having to show that their relocation was consistent with the new objective standards. From the viewpoint of legal policy, it is quite possible that a different remedial outcome would be preferable. An alternative for the court would have been to order the league first to devise objective standards and then decide whether the Raiders met these standards. Such a result would allow the court to hold that the league's decisionmaking apparatus was defective without requiring the court to reward a potentially inappropriate suitor for the Los Angeles location.

The point to be made here is more than trivial. The concern for a second franchise in Los Angeles invites the general question: "But why the Oakland Raiders?" It is possible that the more sound outcome from the point of view of virtually everyone involved would have been for the Raiders to remain in Oakland and for a new franchise to locate in Los Angeles. If the chance to own the Los Angeles franchise were made available to others as well as Al Davis, it is likely that several prospective owners would have appeared. An important policy point is that such an invitation for an open bidding holds the significant prospect for generating a level of competition that would benefit both the Coliseum Commission and local fans, a result which the majority sought to foster. Of course, Al Davis as an individual should be allowed to bid on the new Los Angeles franchise. If successful, he would be required to sell his Oakland franchise to another party.

It is far from clear what the outcome would have been if the majority had asked whether a move by the Raiders could be justified under the rule of reason standard that it announced. There are some factors that suggest that it would be preferable both to leave a franchise in Oakland and establish a new one in Los Angeles. Of considerable importance is the fact that the Oakland franchise was among the most successful in the NFL, both on the field and in its financial affairs. The club had won the Super Bowl and had been a strong divisional contender in several prior years. Financially, the franchise was near the top of the league in revenues received. See Hearings, supra note 8, at 380 (statement of William R. Robertson, Commissioner, Los Angeles Coliseum Comm'n); id. at 521 (statement of NFL Commissioner Pete Rozelle); id. at 616 (statement of Lionel Wilson, Mayor of Oakland, Calif.). Fan support had been significant. But while Oakland had been proven to be a successful location, the Raiders' departure would not necessarily mean that a new franchise could be located there as easily as it could in Los Angeles. There are several reasons why careful league planners might be justified in leaving the established franchise intact. While fan loyalty had been high, a disruptive move by the Raiders most likely would have had an adverse effect. Stated another way, continuing fan loyalty is likely to be considerably easier than rebuilding it. Moreover, while the Oakland market had been developed to the point of success, it is a relatively small market, especially among two-team markets. A new franchise trying to establish itself is likely to experience difficulties in marketing that would not be encountered by an ongoing franchise. Finally, the departure of the Raiders leaves the Oakland market vulnerable to claims by competitors, and thus there is a chance that the market might be lost to the NFL altogether. In fact, a USFL franchise did try to establish itself following the Raiders' departure. The likelihood that a rival entrant would be a threat to the NFL would have been reduced significantly if the NFL had been able to maintain its "coverage" in Oakland.

Some might argue that the court's remedy-allowing the Raiders to move without a showing of an objective justification-was necessary to achieve other goals of antitrust policy. In the absence of 
Judge Williams' dissent forcefully disputed the correctness of the majority's conclusion on the single entity issue. For Judge Williams, the cooperative character of the league suggested that its internal business decisions did not have the conspiratorial character that is the premise of the section 1 prohibition. ${ }^{30}$ Nor was there a realistic concern that a wholesale antitrust exemption would be created. Judge Williams could identify distinctions to be drawn between different types of league activities in terms of their amenability to the single entity characterization. ${ }^{31}$

The balance of this article examines the analytical framework that is offered in the majority opinion in Los Angeles Coliseum. The evaluation made here is devoted exclusively to claims raised by the Raiders against the league. Any potential separate claim of the Coliseum Commission is not reviewed. There are several reasons for the more confined focus. First, the claim of the club is the one that has most relevance for other aspects of league governance. Further controversies most apt to be stimulated by the opinion in Los Angeles Coliseum are those in which individual clubs seek to claim various economic advantages, such as pay television rights, that might previously have been subject to league control. Second, the legal basis for any claim that a stadium owner might make is largely derivative. In other words, if it were concluded, in a particular case or over a wide range of cases, that the league could properly limit the movement of its franchises, it seems unlikely that stadium

the threat of such a significant disruption, it might be contended that the league would have little incentive to conform its franchise rules to the dictates of the antitrust laws. Such an analysis fails to give a sufficient accounting of the very imperfect guidance that the antitrust laws have provided on questions of sports league governance. It is difficult to find much negligence in the league's adherence to its traditional franchising practices. Indeed, the league could well have thought that its actions were authorized. See San Francisco Seals, Ltd. v. National Hockey League, 379 F. Supp. 966, 969-71 (C.D. Cal. 1974) (professional hockey league member was not competing in an economic sense with the league and its other members, so territorial restraints imposed by league did not violate section 1). See also J. WEISTART \& C. LowELl, supra note 12, at 694-705.

Moreover, the hypothesized defense of the court's remedy fails to take account of the availability of alternative remedies that hold the prospect of significant potential "punishment" for the league. For example, even if the Raiders had no ultimate right to move, Al Davis may have suffered damages as a result of having been denied the opportunity to bid on the Los Angeles location. In addition, if one accepts other parts of the court's analysis, there may have been other claimants, including the Coliseum Commission, that had recognizable claims. Finally, the prospect of a generous award for attorney fees plus injunctive relief is likely to provide a significant incentive for a dissatisfied owner to contest a league's practices.

30. Los Angeles Coliseum, 726 F.2d at 1404-05 (Williams, J., dissenting).

31. Id. at 1406 (Williams, J., dissenting). Thus, Judge Williams, unlike the majority, did not find great precedential value in earlier cases which found that certain league restrictions on player mobility violated the antitrust laws. While those cases suggested that sports leagues were not entitled to a true entity exemption from section 1, Judge Williams thought that a principled distinction could be drawn between the league's rules in question in those cases and intraleague controls intended to regulate the production of the clubs' product of professional football. 
owners would have an independent legal basis for producing a different result. Questions concerning stadium leases arise only when there is a prospective tenant with a right to locate in a stadium. When we decide that the league commits no antitrust offense in foreclosing the availability of such a tenant, any complaint by a stadium owner seems to be largely foreclosed. Thus, there is a good deal of value in focusing on the essential question: the right of league members to act collectively to control franchise moves. ${ }^{32}$

\section{The Essential Themes of the Court's Opinion: Conflicting Views of the Role of Competition}

A basic contention of this article is that the majority in Los Angeles Coliseum presents an unsatisfactory appraisal of the role of competition in the sports industry. Once a more coherent view of the potential for competitive behavior is developed, the correctness of the result reached by the court is rendered doubtful. To illustrate the error in the majority's conceptualization of the case, we will, for the moment, step away from the court's technical legal analysis and examine the broader themes of its opinion. The court's view of a league's right to limit a club's effort to pursue its own economic advantage will be particularly scrutinized. For the present discussion, no effort is made to suggest whether it is the single entity defense or the rule of reason analysis that is most affected. As will be seen, when the inherent difficulty in the court's analysis is corrected, the proper outcome can plausibly be accommodated under either doctrine.

One unmistakable implication of the majority's decision is that the league may not always claim to itself-or more precisely, to its collective

32. The majority's treatment of the Coliseum Commission's claims in Los Angeles Coliseum is somewhat curious. In a preliminary discussion intended to identify the relevant market for the balance of its analysis, the court defines a separate market for sports stadium tenants. 726 F.2d at 1394. The court indicates that the stadium owners and the Raiders' owners have distinctive potential claims under the antitrust laws. However, when the court considers the substantive aspects of the rule of reason on the facts before it, it does not elaborate on the separate issues that might arise in connection with the claim of the stadium owner. Most of the factors mentioned by the courtpopulation size, fan loyalty and so on-are relevant only to the general question of whether a club will be allowed to relocate from one area to another. While a stadium owner's claim would be affected by those elements, there are other concerns that are more distinctively related to the suitability of a particular stadium-its size and location, for example. The court's failure to develop the substantive aspects of the stadium owner's separate claim thus leaves the analysis somewhat incomplete. The omission does, however, tend to reinforce the conclusion offered in the text that the antitrust rights of stadium owners are largely derivative. Once we know that a stadium is of adequate size and location, and is otherwise suitable-as it was in Los Angeles Coliseum-the primary antitrust issues remaining are those that concern the propriety of the league's decision to imit the movement of the club in question. 
membership-economic opportunities that could be captured by one of its individual members. Indeed, parts of the opinion suggest that all league actions should be judged from the premise that individual clubs within a league are independent businesses and are free to pursue their own economic advantage, subject to a carefully circumscribed right of the league to impose limited controls. The acceptable controls are those compelled by necessity, specifically the necessity of joint league action to schedule games, foster a league race, and insure the economic viability of the component parts. In framing the broad issue before it, for example, the majority perceives that it must decide whether a group of businessmen can interfere with a co-venturer's "right to do business where he pleases." 33 Although not examined in further detail by the court, this statement assumes as a premise that entrepreneurial autonomy is the natural state and that any different arrangement requires specific justification. In a similar vein is the majority's later statement that

[t]o withstand antitrust scrutiny, restrictions on team movement should be more closely tailored to serve the needs inherent in producing the NFL "product" and competing with other forms of entertainment. ${ }^{34}$

Again, the suggestion is that proper league controls are confined to satisfying certain limited "inherent" needs and then only if the relevant rules are carefully confined. The remainder of economic opportunity is, by implication, to be left to be captured by individual clubs. Further, on the now-critical question of whether there is sufficient reason for collective control, the Ninth Circuit majority seeks objectification. The court found offensive the NFL procedure that allowed member clubs to cast raw, unexplained votes on the issue of franchise moves. In the court's view, the need for choosing the least restrictive alternative and thus minimizing the restraint on individual owner prerogatives required the league to draw its decision as carefully as possible, and that implied the need for standards such as relative population size, television marketing effects, and so on, against which the proposed move would be judged.

As an aside, it can be noted that the model of league decisionmaking that this view presumes is much different from that which has operated in the past. Legal rules gave league participants little reason to confine collective decisions on matters relating to the development of franchises and the dispersal of the economic rewards therefrom. Most leagues assumed that they had authority to prohibit the relocation of existing

33. Los Angeles Coliseum, 726 F.2d at 1391 (emphasis added).

34. Id. at 1397. 
franchises, ${ }^{35}$ to deny transfers of ownership, ${ }^{36}$ to decline to add new clubs, ${ }^{37}$ to assess "compensation" when one club was allowed to invade another's territory, ${ }^{38}$ to compel the sharing of gate receipts and broadcast revenues, ${ }^{39}$ and in a few cases, to compel collective financial support for individual franchises. ${ }^{40}$ Which, if any, of these actions will now be allowed is subject to considerable debate. For present purposes, it is enough to note that there is an important conceptual shift if it is true that entrepreneurial opportunities belong to individual clubs, subject only to

35. See San Francisco Seals, Ltd. v. National Hockey League, 379 F. Supp. 966, 968 (C.D. Cal. 1974); see also Hearings, supra note 8, at 517 (statement of NFL Commissioner Pete Rozelle concerning NFL effort to forestall move by Baltimore Colts); N.Y. Times, May 19, 1983, at B17, col. 5 (National Hockey League (NHL) blocks sale and move of St. Louis Blues to Saskatoon). For a discussion of franchise moves in baseball, which are probably exempt from antitrust scrutiny because of baseball's exemption, see Quirk, An Economic Analysis of Team Movements in Professional Sports, 38 LAW \& CONTEMP. ProBS., Winter-Spring 1973, at 42, 49-52.

36. See Levin v. National Basketball Ass'n, 385 F. Supp. 149, 150 (S.D.N.Y. 1974); see also Comment, The Super Bowl and the Sherman Act: Professional Team Sports and the Antitrust Laws, 81 HARV. L. REv. 418, 426-30 (1967). Cf. N.Y. Times, Jan. 8, 1982, at A17, col. 1 (proposed sale of Seattle SuperSonics to company which manufactures slot machines to be reviewed by National Basketball Association (NBA)); Washington Post, May 20, 1983, at D5, col. 3 (among reasons for NHL disapproval of move of St. Louis Blues to Saskatoon is prospect of public ownership of franchise).

37. See Mid-South Grizzlies v. National Football League, 550 F. Supp. 558, 561 (E.D. Pa. 1982), aff'd, 720 F.2d 772 (3d Cir. 1983); see also Hearings, supra note 8, at 273-82 (testimony of NFL Commissioner Pete Rozelle concerning league expansion policies).

38. See N.Y. Times, May 28, 1982, at A17, col. 1 (Colorado Rockies pay $\$ 12.5$ million compensation to New York Rangers, New York Islanders, and Philadelphia Flyers in connection with move to New Jersey); id., July 27, 1977, at A1, col. 1 (NBA Nets paid $\$ 4$ million "compensation" to New York Knicks when the Nets moved to New Jersey).

39. As previously noted, the NFL has historically engaged in extensive revenue sharing. See supra note 16 and accompanying text. Practices in other leagues vary. While the NFL shares gate receipts $60-40$, there is no gate sharing in basketball and a modest sharing in baseball. The totally equal division of national television revenues in the NFL is followed in baseball, but in the latter sport local broadcast revenues, a significant source of revenue, are not shared. Basketball divides a modest national television contract equally, but also does not share important local revenues. See Hearings, supra note 8, at 66-69 (testimony of Gerald W. Scully); J. MARKhaM \& P. TEPLITZ, Baseball Economics and Public Policy 89-93 (1981); Noll, The U.S. Team Sports Industry: An Introduction, in GOVERNMENT AND THE SPORTS BUSINESS, supra note 17, at 1, 13-29.

The NBA appears to be prepared to endorse an arrangement of direct cross subsidization that is more venturesome than traditional forms of revenue sharing. See infra note 80.

40. Frequently such support is required to assist franchises that encounter financial difficulty. See Sports Indus. News, May 23, 1984, at 87 (USFL assumes control of Chicago Blitz franchise; seeks settlement with creditors); L.A. Times, Oct. 8, 1975, Pt. I1I, at 4, col. 1 (WFL members assessed to support Portland franchise). The internal league subsidy may also take the form of a belated agreement to subordinate league debts to those of other creditors, as happened in the NBA. See N.Y. Times, June 16,1977, at D15, col. 1 (NBA agrees to extend time for payment of entry fee by clubs that previously came from American Basketball Association (ABA); also agrees to subordinate debt). A related type of collective support is seen in the decision of the twelve owners of the then-recently formed World Hockey Association (WHA) to share the cost of the bonus paid to Bobby Hull to jump from the NHL to the Winnipeg franchise in the WHA. See Quirk \& El Horidi, The Economic Theory of a Professional Sports League, in Government AND THE SPORTS BuSINESS, supra note 17 , at 33,41 . 
league controls arising from necessity. Just as unfettered league control of franchise moves could no longer be presumed under the view put forth in the majority opinion, neither could the league be assured that the collective control over gate receipts, broadcast revenues, and ownership transfers would fall beyond judicial review..$^{41}$

The court's urging of greater economic freedom for individual clubs permeates its substantive antitrust analysis. In the court's view, a finding of liability requires a showing that there is " (1) an agreement among two or more persons or distinct business entities; (2) which is intended to harm or unreasonably restrain competition; (3) and which actually causes injury to competition." "42 The court, of course, found that each element was satisfied. What exactly was the "competition" that was injured? For the majority, the NFL rule produced an injury to competition in the local market for NFL football. In other words, the court accepted-or more precisely, found that there was sufficient evidence for the jury to accept-that the relevant geographical market was the local market, that the relevant product was NFL football, and that competition among NFL teams would be enhanced if Rule 4.3 were invalidated. The court made clear the policy goal it hoped to achieve by applying the antitrust laws in this case. It had a concern for monopoly pricing. Indeed, for the majority, the matter was rather simple:

[t]he competitive harms of Rule 4.3 are plain. Exclusive territories insulate each team from competition within the NFL market, in essence allowing them to set monopoly prices to the detriment of the consuming public. ${ }^{43}$

What the court envisages, apparently, is that the introduction of a competing team in Los Angeles will force each club to compete for fans and hence will lead to competition in ticket pricing, which, the court believes, will produce lower prices and avoid those despised monopoly profits. ${ }^{44}$

At a superficial level, this pursuit of the free market meshes nicely with the court's view of the right of clubs to capture entrepreneurial opportunities. The market will be free only if the actors are free, and this is achieved only by the careful confinement of centralized league control. Thus, the league's authority must be restrained to allow the benefits of competition to flow to consumer-fans.

41. See supra note 8.

42. Los Angeles Coliseum, 726 F.2d at 1391 (quoting Kaplan v. Burroughs Corp., 611 F.2d 286, 290 (9th Cir. 1979), cert. denied, 447 U.S. 924 (1980)).

43. Los Angeles Coliseum, 726 F.2d at 1395.

44. The majority promotes a similar theme earlier in the opinion when it asserts that cartel behavior by owners should be condemned. The justification for such condemnation is that cartcl behavior enables competitors "to charge unreasonable and arbitrary prices instead of setting prices by virtue of free market forces." Id. at 1392. 
Upon closer examination, however, a substantial question arises as to whether the goal of increased competition among NFL clubs provides a satisfactory rationale for pervasive limits on joint decisionmaking by the clubs comprising a professional sports league. When probed, the court's notion of "competition" seems at best incomplete and at worst illconceived. ${ }^{45}$ Indeed, the court itself seems to abandon the model of internal competition when it considers the league's justifications for its actions.

No small part of the difficulty with the court's opinion arises because the majority treats each of the elements of an antitrust offense discretely. The matter of identifying the local market as the relevant one is undertaken without regard to the substantive antitrust treatment of league franchise controls. The former is discussed and the virtues of "competition" are extolled early in the opinion and the latter is taken up much later. There is no serious attempt to intertwine these bedrock issues. ${ }^{46}$

Unfortunately, the issues cannot be segmented so neatly. The court's later analysis does agree that leagues can exercise control over franchise locations. Particular attention must be given to the goals that the court concedes can be pursued by a league as it asserts its collective interest. Of critical importance is the court's acceptance that a proper goal of league franchise controls is to insure the financial stability of the clubs involved. The court recognized that such stability both promotes on-the-field competition and is important to the economic interests of other venturers:

We agree that the nature of NFL football requires some territorial restrictions in order both to encourage participation in the venture and to secure each venturer the legitimate fruits of that participation. . . . Exclusive territories aid new franchises in achieving financial stability, which protects the large initial investment an owner must make to start up a football team. Stability arguably helps ensure no one team has an undue advantage on the field. ${ }^{47}$

45. The court's analysis may also be wrong as a matter of economics. There is respectable authority to suggest that intraleague competition has little if any effect on ticket prices. One study found that ticket prices were not substantially lower in multiteam cities. See infra note 54. Such a finding in the context of Los Angeles Coliseum would, of course, substantially undermine the pivotal premise of the majority's analysis.

46. The majority states that it regards the question of the relevant market to be related to the question of the nature of the entity involved. Las Angeles Coliseum, 726 F.2d at 1394. The court also states that the ultimate question of legality subsumes both issues. Id. The opinion, however, fails to recognize that the concessions ultimately made to league control significantly limit, if not eliminate, the prospects of traditional competition between two clubs in the same city.

47. Id. at 1396. Some might find significance in the fact that the majority only refers to "new franchises" in its first reference to financial stability. There is, however, no serious basis for sug- 
What the court apparently fails to appreciate is that the collective concern for the financial stability of individual franchises is at odds with its assumption that there will be free and robust competition. References to a "free market" 48 and "monopoly prices" 49 reflect premises that are fundamentally inconsistent with those that underlie a recognition of the financial interdependence of league members. As eventually characterized by the court, the law seems not to require that two franchises be established as fierce competitors. Indeed, it appears that a portion of the relevant market may be assured to each. ${ }^{50}$ Thus there are considerable grounds for doubting the extent to which the prerogatives of individual clubs have been enhanced.

The tension between a league's concern for financial stability and a call for increased competition warrants elaboration. The recognition of the clubs' mutual interest in the financial stability of each club should mean that a league can decline to locate a franchise in any area in which it appears that available fan support would be inadequate. This should be true whether the proposed franchise is the first, second, or third for the particular area. In the same vein, the court's analysis presumably allows the league to insure that there will be enough fans to support each new franchise. ${ }^{51}$ If there are sufficient fans to support one but not two franchises, then-under the court's rationale-the league would be required to locate only one club in the area. And before two are required, it must be clear that there are enough fans to provide support for each. In effect, each franchise is allowed an assured fan base. A structure that accepts this fact is considerably different from the free market that the majority loosely espouses.

In fact, because the fan base in particular locales will never precisely equal the number reasonably needed to support a given number of franchises, there will usually be more than enough potential fans to support the franchises that are assigned. Put in simple terms, if a successful football franchise requires a population base of at least $x$, then a city with

gesting that the concern for the relationship between financial stability and on-the-field competitiveness is relevant only to new franchises.

48. See supra note 44.

49. See supra note 43 and accompanying text.

50. In addition to giving its approval to the use of some type of territorial restriction, the majority lists the objective factors that it believes should control the decision. Among these are "population, economic projections, facilities, regional balance, etc." Los Angeles Coliseum, 726 F.2d at 1397. While the majority gives no detailed elaboration, the references to population and economic projections presumably are intended to suggest that a move would not have to be approved if the population base were insufficient to support the additional franchise or if the economic projections werc negative.

51. See supra note 50 . 
a population of $1.5 x$ will be allocated only one franchise, which will enjoy a substantial cushion of additional potential patrons. ${ }^{52}$ And in an area with a population of $2.75 x$, a league presumably needs to award only two franchises, with the additional $.75 x$ population providing an excess of fans for each club.

The success of a particular franchise, of course, will depend on a variety of factors in addition to the size of its fan base. The overall quality of the league product, the astuteness of club decisions with respect to personnel, and the availability of entertainment alternatives will all substantially affect whether the franchise succeeds. But even with the financial uncertainty that is introduced by these factors, the essential point remains: under the majority's concession, a league will never be required to put two of its franchises in a locale in which one will operate from a position of substantial weakness. Subject to the uncertainties inherent in any business planning and subject to subsequent developments that might diminish the commercial viability of the planned athletic competition, a league presumably can make its franchise allocation decisions on the assumption that each franchise is entitled to an assured, protected market. $^{53}$

The point, again, is that if the court's eventual analysis of league interests is correct, there is not likely to be a free market for NFL football. The latter view suggests that the league can regulate the award of franchises to insure that other league goals - specifically the financial stability of each individual club-is not undermined. The decisionmaking process, permitted by the concession in the majority opinion, will be one

52. A surprisingly durable notion among courts and legal commentators considering franchising issues is that there is a definable minimum population base necessary to support a sports franchise. See, e.g., American Football League v. National Football League, 205 F. Supp. 60, 76 (D. Md. 1962), aff'd, 323 F.2d 124 (4th Cir. 1963); Glick, supra note 17, at 92; Kurlantzick, Thoughts on Professional Sports and the Antitrust Laws: Los Angeles Memorial Coliseum Commission v. National Football League, 15 ConN. L. REV. 183, 206 (1983); see also Sports Antitrust Reform Act, H.R. 2129, 96th Cong., 1st Sess. (1979). Presumably that number varies from sport to sport and changes over time with variations in the cost of operating a franchise and the popularity of the particular league's product.

One study that attempted to quantify the relationship between population and other variables in their effect on baseball attendance found, not surprisingly, that the size of the population base is perhaps the most important consideration in a club's financial success. But it is also not surprising that the relative success of the team and the number of star players on its roster were found to have a significant effect on total attendance and ultimate profitability. Nonetheless, a team with modest onthe-field success is likely to do better financially in a city with a large population base rather than a small one. See Noll, Attendance and Price Setting, in GovernMENT AND THE SPORTS BusINEss, supra note 17, at 115, 120-30; see also J. MARKhAM \& P. TEPLITZ, supra note 39, at 67-73.

53. Again, this is a notion that is accepted by most commentators, including those who would subject league franchise decisions to more exacting judicial scrutiny than is advocated in this article. See Glick, supra note 17, at 92; Kurlantzick, supra note 52, at 196. 
that emphasizes the need to protect each franchise from ruinous competition. This is obviously a much different notion than that which earlier prompts the court to condemn "monopoly prices" and demand "free market" behavior.

What causes this difficulty in the majority's treatment of the case? A major conceptual hurdle for the majority-and for many commentators dealing with sports-related antitrust issues-is the prospect of some competition for fans between two clubs located in the same geographical area. The potential for such occasional competition is frequently seized upon as the lodestar for an antitrust analysis. Seldom is consideration given to the more basic issues of whether such competition is merely transitory and whether it might be largely irrelevant for antitrust purposes. ${ }^{54}$ Unfortunately, the prospect that under some circumstances two clubs might, contrary to their preferences and to the predominant interest of their fellow venturers, attempt to sway the allegiance of local fans has had a decided diversionary effect. Not infrequently attention is drawn away from an analysis of the predominant and most enduring characteristics of the league's venture. And as is illustrated by Los Angeles Coliseum, the discussion sometimes ignores the inevitable need for reconciling the potentiality of competition with the league's ultimate right to insure its own financial stability.

54. Surprisingly absent from the court's analysis in Los Angeles Coliseum is any reference to the significant work done by academic economists who have looked at the sports industry. One of the more interesting studies was done by Professor Jesse W. Markham of the Harvard Business School and Paul V. Teplitz of the Cambridge Research Institute. J. MARKhaM \& P. TEPLITZ, supra note 39. While Markham and Teplitz focused on professional baseball, much of their analysis has relevance for other leagues. Their observations about the role of local competition raise a substantial doubt about the correctness of the court's approach:

While clubs constituting a league compete with one another for league standing, they do not, because of the geographical nature of the "market," compete for customers. . . . This is not meant to imply that absolutely no competition for customers exists among majorleague clubs. The four large metropolitan areas supporting two or more clubs may be characterized by a certain amount of interclub competition for patronage and fan loyalty. Moreover, the network telecast of a major-league game may compete with a hometown game played on the same day. The essential point, however, is that such fringe competition is not likely to affect the decision making of individual clubs in such matters as ticket prices. Thus, ticket prices are likely to be determined not by competition with other clubs but by competition with alternate uses of people's leisure time, such as television, going to the beach, or puttering around the yard. The revenues earned by a club with any given home game are determined much more by its own league standing and its relative standing with the visiting team than by any independent competitive commercial strategy it may adopt against other teams in its league. ... In economic terms, the price cross-elasticity of demand among games played in different home parks is extremely low-in fact, in most cases it is virtually zero.

Id. at 23-24 (footnote omitted). The authors also noted that "price competition does not occur to any great extent in multiteam cities. Ticket prices for such teams are not significantly different from prices charged by other teams." Id. at 23 n.12. 
There are several difficulties with this view of the role of "competition." One is the lack of perspective in the view taken of the competition that may occur. What is missing from Los Angeles Coliseum is an appreciation of the extent to which economic competition among clubs is an incidental and usually avoidable aspect of the league's economic venture. 55 It is certainly not inevitable. Presumably each local team would prefer sold-out stadiums; and as we noted, the league presumably could structure its affairs to foster this result, for the league need not purposely allocate a franchise to an inadequate population base. Because the league's planning cannot be precise, however, and because the local franchises are subject to dynamic economic forces, competition for fans may develop from time to time in a two-franchise city. But the occasional and incidental competition that results should not-and indeed, cannot-become a goal of legal policy if recognition is given to the more basic interdependent characteristics of the league. ${ }^{56}$

The point here can be underscored by reference to extreme examples of interclub competition. Imagine the case in which significant competition developed between two football franchises in a given locale. Assume that it intensified to the level that one franchise was able to attract a significant number of fans from the other, and the financial fortunes of the latter were jeopardized. In most business settings, we would accept this as a necessary, and frequently desirable, consequence of the free market, because some deficiency in the weakened franchise had been exposed. The situation, however, is likely to be viewed differently in the sports context. Presumably, consistent with its goal of preserving each

55. Another contextual point ignored in Los Angeles Coliseum is that, over the history of professional sports, two-team cities have rather persistently been the source of financial concern for the leagues involved. Thus, the league's actual experience stands in some contrast to the benefits that the majority implies will flow from having more such competition. The experience in Boston, St. Louis, and Philadelphia in baseball and in Chicago, Baltimore-Washington, and San Francisco-Oakland in football should suggest that economic stability and dual league representation are often difficult to sustain over time. See, e.g., Quirk, supra note 35, at 47-63. Hence, the league's concern for the financial implications of a two-team locale does not seem to be a matter that can be trivialized. In the same vein, the supposed benefits of competition are likely to be transitory in many locales.

56. This raises the legitimate question of what issue of legal policy is presented by Los Angeles Coliseum if it is not a question of increased competition. As a later portion of this article suggests, see infra notes 68-76 and accompanying text, the real issue may not be whether we should encourage more local competition between franchises, but rather whether there is an inadequate penetration of the market for franchises by the NFL. As will be indicated, the latter question arises even in cities in which only one franchise can be supported and which thus offers no significant prospect of "local competition." It will be suggested that section 2, rather than section 1, of the Sherman Act may have the more significant implications for market penetration. See id. An alternative view is that the market for professional sports franchises has structural imperfections and may require a legislative solution. The present discussion accepts that there are market imperfections, but does not undertake to consider the legislative responses that might be appropriate. 
member's financial stability, the clubs within the league would be permitted to intervene and save the weakened franchise from ruin. There must, of course, be corporate authorization for such action, but as far as the antitrust laws are concerned-even in the majority's ultimate analysisthere appears to be no principle that requires the co-venturers to sit by and accept the worst consequences of interclub competition.

There is a second conceptual weakness that results from the court's attempt to use "competition," particularly "local competition," as the justification for its effort to decentralize the governance of professional sports. An apparent theme of the opinion is that league control is to be circumscribed, and individual clubs are to be presumed to have the right to capture available entrepreneurial advantages. Yet there is very little potential for "local competition" within the NFL, or indeed in most professional leagues. In the NFL, the norm is the single franchise city. At present, "local competition" in a meaningful respect can occur in only two locales, Los Angeles-Orange County and New York-New Jersey. Thus, while the court purports to announce a reform that would have league-wide effects, the premise from which it operates appears quite incapable of supporting such a broad conclusion. In fact, in the typical NFL city, restrictions on the extent of franchise controls may have effects contrary to those which the court thought it was pursuing. A single location franchise presumably could use its new freedom to exact further profits-or as the court says, "monopoly prices"-from local fans. This might, for example, take the form of an effort to assert control over local distribution of the broadcast of the team's "away games." 57

In terms of developing a coherent antitrust policy, the difficulty here is more than trivial. If the subject city in Los Angeles Coliseum were not Los Angeles, but rather Phoenix, Memphis, Indianapolis, or another locale that was previously unoccupied but capable of supporting only a single NFL team, it is not obvious that a section 1 theory would have protected the Raiders' move. Section 1 is intended to proscribe conduct that limits competition. If the relevant market is local and if the particular locale in question can sustain only a single franchise, it is quite uncer-

57. There is another potential irony that might be noted. The move by the NFL Colts from Baltimore to Indianapolis occurred after the Ninth Circuit's decision in Los Angeles Coliseum. While the precise impact of that case on the NFL decisionmaking cannot be known by an outsider, it appears that the league's decision not to challenge the move was infuenced by the prospect of further antitrust liability premised on the Ninth Circuit precedent. See Sports Indus. News, Apr. 11, 1984, at 59. It should be noted, however, that the Colts moved from an area of potential local competition-Baltimore-Washington-to a city where the team will enjoy a virtual monopoly. Thus, a case that supposedly seeks to save fans from the vice of "monopoly prices" seems to have had the opposite effect. See also L.A. Times, July 31, 1984, Pt. III, at 1, col. 2 (Colts offer 52,000 season tickets; receive orders for 143,000 ). 
tain how a league bar to relocation would reduce competition among producers of NFL football. ${ }^{58}$ Again, it appears that the majority in Los Angeles Coliseum expects a modest notion of "local competition" to provide the foundation for a concept that has overpowering dimensions. ${ }^{59}$ But without this premise, there is little antitrust substance in the alleged section 1 offense.

A final weakness in the court's notion of competition is related to the first criticism raised above. In castigating monopoly profits and extolling the "free market" in the first portion of the opinion, the court apparently believes that it is conforming sports to the consumer welfare model of antitrust. That model assumes that consumers will benefit from more economic competition and well-rewarded competitors. ${ }^{60}$ In the peculiar economics of professional sports, however, that is not the case, at least not at the level of intraleague relations. There is a need for balance and equality in playing strength among league franchises. ${ }^{61}$ Without some centralized control, the economic success-or failure-of one or several clubs can significantly reduce the value of the product that is offered. The real "product" is not one that any single team controls, ${ }^{62}$ but

58. This issue has a potentially significant effect on the precedential impact of the Los Angeles Coliseum decision. If protection of local competition is an inherent part of the court's rationale, then it is not clear how the case could be used to review a league decision to prevent a team from relocating to a city that could support only a single franchise. The subsequent move of the Colts from Baltimore to Indianapolis raises this concern. See supra note 57.

59. In one passage, the majority puts forth its view that NFL clubs compete for "players, coaches, and management personnel." Los Angeles Coliseum, 726 F.2d at 1390. Some might suggest that it is this competition that provides a rationale to sustain a section 1 review even in cases involving a move to a single team city. It might be suggested that movement of a club may enhance its ability to compete for these various types of employees. The court, however, does not utilize this theory and it is debatable whether any plaintiff in Los Angeles Coliseum had standing to raise the concerns of the parties identified. Moreover, any serious pursuit of such an approach would have to confront the fundamental question whether these other parties are so significantly affected by the location of a franchise as to outweigh the justifications for giving the league broad discretion to control franchise movements. The presence of separate markets for the various types of employees should raise doubts as to whether the relative profitability of a single competitor will have an appreciable effect on the prices paid for their services.

60. That the goal of consumer choice is to be the guiding principle in American antitrust law was reconfirmed by the Supreme Court in NCAA v. Board of Regents, 104 S. Ct. 2948, 2963-65 (1984).

61. The notion that balanced on-the-field competition is important to the success of a sports league is now generally recognized among courts and commentators, even those strongly critical of traditional league practices. A sampling of the sources that would support this conclusion can be found supra notes 17-18.

62. Both the district court and the court of appeals in Los Angeles Coliseum assert that each team within a league offers a separate product. 519 F. Supp. at $583 ; 726 \mathrm{~F} .2 \mathrm{~d}$ at 1388 . This conclusion is contrary to a substantial body of economics literature. The joint nature of the sports product involved in a league game has long been recognized. See, e.g., H. DEMMERT, supra note 17, at 10; J. Markham \& P. Teplitz, supra note 39, at 19-20; Neale, The Peculiar Economics of Professional Sports, 78 Q.J. EcoN. 1, 3 (1964). 
rather is that which results when teams from other clubs appear in a structured athletic contest which is part of a larger league race. Thus, even were one team to gain a significant advantage over others, through control of television receipts or by some other means, that does not tell enough to allow us to conclude that consumer welfare has been advanced. What is necessary is an additional appraisal of the final product-both the local team's contribution to it and the level of competitiveness of the visitor. Such analysis may well make one skeptical that consumers will always prefer the results of increased autonomy. If what fans find attractive is not merely the offering of the local team, but rather an intense, sustained competition in which local teams participate, then presumably the fans' interest is furthered by rules that lead to equalization rather than imbalance. ${ }^{63}$

The majority opinion eventually recognizes this point when it discusses the substance of the rule. ${ }^{64}$ But the failure to reconcile the demand for increased competition and the recognition of the value of league control is of fundamental importance. If it is in fact true that a misdirected model of consumer welfare is used to sustain the court through its discussion of the desirability of increased competition, then the later discussion of the substantive impact of the rule of reason may have been unnecessary. In fact, a finding that the competition to be protected was not that which occurs between two local NFL teams, but rather the competition that exists between the NFL and other forms of entertainment, would have brought the opinion to a quick conclusion. ${ }^{65}$

So, what exactly does Los Angeles Coliseum mean? Ultimately one cannot be sure. The majority attempts to strike a blow in favor of greater entrepreneurial prerogatives for individual member clubs within a league. Its pronouncement, however, suffers from both an imperfect premisethe overstated utility of inter-club competition - and a conclusion that is

As explained in more detail below, the court's assertion that each team produces a singular product also proceeds from a highly doubtful legal assumption about a club's ability to control its own assets. See infra notes 99-109 and accompanying text.

63. In addition to the economic commentaries that support this view, see supra note 62 , the essential point about the need for equalization of playing strength has received wide recognition in the decided cases. See, e.g., North American Soccer League v. National Football League, 670 F.2d 1249, 1251 (2d Cir. 1982); Mackey v. National Football League, 543 F.2d 606, 621 (8th Cir. 1976); Mid-South Grizzlies v. National Football League, 550 F. Supp. 558, 560 (E.D. Pa. 1982), aff'd, 720 F.2d 772 (3d Cir. 1983).

64. Los Angeles Coliseum, 726 F.2d at 1396.

65. In undertaking to identify the competition most relevant for antitrust purposes, some attention should have been given to the view put forth by Markham and Teplitz that in two team cities, ticket prices are less apt to be influenced by interteam competition than by other considerations such as the availability of entertainment alternatives. J. MARKHAM \& P. TEPLITZ, supra note 39, at 2324. This finding adds weight to the view put forth in the text. See also supra note 54. 
contradicted by the court's own recognition of the need for financial stability in individual franchises. If a showing of a promotion of local competition is needed each time a club claims an entrepreneurial advantage, then the precedential value of the case may be quite limited.66 There is, though, another possibility, and that is that the basic thrust of the case needs reexamination.

\section{Alternative Antitrust Theories: AN Overview}

The preceding analysis of Los Angeles Coliseum has identified the essential weakness of the majority opinion: the outcome supposes an enhancement of competition among league clubs, but it is extremely doubtful that such competition will occur if the league is permitted to pursue other goals seemingly accepted by the court, particularly the goal of insuring the financial strength of the league's constituent members. There is thus an apparent and significant flaw in the court's analysis. The question naturally arises, then, as to what would be a more appropriate legal theory to apply to the facts before the court.

This question invites several responses. At a preliminary level, there are grounds to suggest that there is no section 1 violation in Los Angeles Coliseum and that the result reached is therefore incorrect. A premise of section 1 is that there are competitors which, but for the disputed restraint, would be enhancing consumer welfare through competition. If this supposition does not provide an adequate justification for prohibiting league control of franchise moves, then section 1 seems not to offer a proper basis for liability. Some may observe, however, that the objection still remains that the NFL has not provided football fans with as many local franchises as they might be willing to support. ${ }^{67}$ Under this approach, doubts about the appropriateness of section 1 do not answer the basic concern.

The complaint about incomplete market development by the NFL may be closer to the concerns that underlie section 2 of the Sherman Act, ${ }^{68}$ rather than section 1 . Section 2 proscribes improper market domi-

66. See supra note 57.

67. Professor Roger Noll of the California Institute of Technology has provided the economic analysis that suggests why this might be so. See Noll, Attendance and Price Setting, in GoverNMENT AND THE SPORTS BuSINESS, supra note 17, at 115, 141-46. See also Hearings, supra note 8, at 163-64 (letter from Roger G. Noll). Others have agreed that the market for sports franchises is not one controlled by the normal competitive forces and may require some form of public regulation. See Quirk, supra note 35, at 64-65.

68. The prohibition of section 2 extends to "[e]very person who shall monopolize, or attempt to monopolize, or combine or conspire with any other person or persons, to monopolize any part of the trade or commerce among the several States, or with foreign nations." Sherman Act, $\S 2$, ch. 647, 26 Stat. 209, 209 (1890) (codified as amended at 15 U.S.C. $§ 2$ (1982)). 
nation by a single actor. A critical premise of the provision is that abusive exercises of monopoly power must be regulated through legal institutions because the normal pressure of market forces will be insufficient to insure that consumer welfare is advanced. Viewed from the perspective of section 2, the complaint against the NFL is that it enjoys a near-monopoly position in professional football and its dominant market position limits its incentive to satisfy all the demand that might exist for additional franchises. ${ }^{69}$

The relevance of section 2 concerns must not be overlooked. Assume that the NFL had organized itself in a different fashion. Specifically, let us assume that prior to the Los Angeles Coliseum litigation, the NFL was organized as a formal partnership and that the parties had traditional partnership attributes-they shared profits and losses, participated equally in decisionmaking, and were governed by a pervasive collective authority. Such an organizational form would surely render the league a single entity and would remove its activities from the purview of section $1 .{ }^{70}$ The prohibition on conspiratorial behavior therefore would not apply, and there would be no section 1 theory to sustain the result in Los Angeles Coliseum. But the basic complaint concerning the league's failure to fully develop the Los Angeles market would remain. There would still be concerns that a potentially significant consumer demand was unmet and, if one adopts the majority's reasoning, that those fans who were able to see live NFL performances were paying excessive prices for their tickets.

What this example does, of course, is approximate the situation that would exist if the majority had developed a more consistent view of the league's interest in cooperative behavior. There does not appear to be a significant potential for greater market penetration resulting from truly competitive behavior, because the league would not be required to cause clubs to compete against one another. And in single franchise cities, there is not likely to be any competition at all. The outcomes here are similar to those that would obtain if the league were organized as a wholly-integrated entity. Hence, while there may be a complaint about market penetration, it is not a complaint that necessarily draws signifi-

69. Noll suggests that leagues maintain a scarcity of franchises in order to enhance the value of existing teams. Such scarcity also gives clubs increased bargaining power in dealing with stadiums. See Noll, Alternatives in Sports Policy, in Government AND the SPORTs BuSINEss, supra note 17, at 411,412 . From the perspective of public policy, scarcity also serves ends that may be regarded by some as less ignoble. Noll accepts that playing quality is higher if franchises are limited; further, the availability of alternative sites serves a legitimate business objective by preserving some locations as potential home sites for existing franchises that encounter financial difficulty. Id.

70. The duality requirement of section 1 is treated in the text accompanying notes 12-14. 
cance from the concerns for inter-entity competition under section $1 .^{11}$ As suggested, even under the rule of Los Angeles Coliseum, competition is not assured. Perhaps then the real objection is to the monopolist-like behavior that the league engages in with respect to market development. ${ }^{72}$ Such an objection has a decided section 2 ring to it.

Other sources elaborate the relevant section 2 concerns. ${ }^{73} \mathrm{~A}$ full factual investigation of the development of the NFL could well reveal the presence of colorable section 2 claims. But the factual inquiry would have to show more than that the NFL possessed monopoly power. Under section 2 monopolies are not automatically condemned. ${ }^{74}$ The essence of section 2 regulation is a finding that market power has been misused, in particular that it has been used improperly to acquire a monopoly position or to extend it. ${ }^{75}$ That is a question worth investigating. The objection, though, is not one that a fellow cartel member, such as the Raiders club, should be allowed to raise. ${ }^{76}$ Moreover, such a complaint requires a factual record different from that developed in Los Angeles Coliseum.

Another very distinct possibility is that the matter of franchise allocation requires a legislative solution. It appears that normal market forces will not insure that an optimal number of franchises will be established. Such market imperfections frequently provide the justification for regulation. A particular attraction of a legislative response is its capacity to avoid the narrowness of the Los Angeles Coliseum case. That decision considered only the issue of franchise relocation and left unaddressed the closely related issue of league expansion. In addition, the particular legal theory used in the case does not allow for participation by all interested parties. Among those who might have wished to be heard are the disap-

71. This analysis is also germane to another point that has arisen in the debate over the antitrust status of sports leagues. It is occasionally suggested that a finding that a league is a single entity would effectively exempt the league from the antitrust laws. See, e.g., Hearings, supra note 8, at 368 (statement of William R. Robertson, Commissioner, Los Angeles Coliseum Comm'n) ("effect of declaring the NFL to be a single entity would be to bestow on the NFL absolute carte blanche to disregard the antitrust laws"). However, as the text here suggests, that is not correct. While the single entity characterization would preclude further inquiry under section 1 of the Sherman Act, section 2 and all other antitrust provisions would be wholly applicable.

72. Professor Quirk, in his excellent study of franchise movements, concluded that the problem of unresponsive league decisions was a product of the monopoly characteristics of the league. See Quirk, supra note 35, at 64-65. His doubts about the capacity of the marketplace to provide the necessary correctivc are consistent with the theme of this articie.

73. See, e.g., E. GEllhorN, supra note 13, at 84-139; L. Sullivan, supra note 13, at \$§ 19-58; J. WeistaRT \& C. LowelL, supra note 12, at 687-92, 705-33.

74. See, e.g., 3 P. AREeda \& D. Turner, ANTITRust LAw $\S \S 614-623$ (1978); E. GellHORN, supra note 13, at 112; see also United States v. International Harvester Co., 274 U.S. 693, 708 (1927); United States v. United States Steel Corp., 251 U.S. 417, 451 (1920).

75. See J. WeistarT \& C. Lowel, supra note 12, at 714-24.

76. Id. at 702-05. 
pointed Oakland fans, other potential purchasers of a new Los Angeles club, and other potential recipient cities of a relocated Oakland franchise. The legislative forum offers an attractive opportunity for a broadened perspective.

There is, though, more that can be said about Los Angeles Coliseum as a section 1 case. Specifically, there is a question as to which of two explanations provides the most appropriate response to the section 1 issues that are raised. The absence of any prospect of a significant increase in intraleague competition can be taken to mean that the league behavior in question does not violate section 1. There may be differing views, however, as to how this conclusion is to be reached. From one perspective, the error of the case is in the majority's rule of reason analysis. It could be contended that the league's franchise controls were procompetitive in that they furthered the cooperative nature of the league's venture and enhanced its economic stability vis-a-vis other entertainment products. ${ }^{77}$ Conversely, significant limitations on the league members' joint control over market penetration would impede the league's ability to respond to the dictates of its inherent economic interdependence and impair the output of its joint product. An alternative view is that the rule of reason issue need not be reached. From this perspective the court erred in its basic characterization of the nature of the defendant league, at least with respect to franchising decisions. Specifically, the court's treatment of the single entity issue would be disputed.

Each of these views is considered below. They are not, however, dramatically different conceptions. A point not fully recognized in the literature considering antitrust issues in the sports industry is that the single entity theory and a rule of reason analysis sympathetic to the need for internal league controls are variations on the same theme. ${ }^{78}$ The unifying concept is the economic interdependence of the league participants and their need for cooperative decisionmaking. The premise of the single entity theory is that the degree of interrelationship is so extensive that league participants can fairly be said to be co-venturers pursuing a common end. If the league participants had chosen to organize themselves as a corporation or formal partnership and ceded ultimate authority to the agreed-upon entity, there would be complete singularity and little justification for demanding internal competitive behavior. Lesser degrees of economic integration shade the antitrust characterization. There are few guidelines to help a court deal with the many gradations

77. See NCAA v. Board of Regents, 104 S. Ct. 2948, 2967-68 (1984); Broadcast Music, Inc. v. CBS, 441 U.S. 1, 22-24 (1979).

78. See, e.g., Glick, supra note 17, at 59-60 (attempting to distinguish single entity theory of professional sports leagues from the joint venture theory). 
that are likely to occur. ${ }^{79}$ But presumably we must be prepared to accept that some organizational forms less formal than a traditional corporation or partnership may remain beyond the ambit of section $1 .{ }^{80}$

79. A common form of analysis offered by opponents of the single entity theory tracks the following format. The league says it should be treated like a partnership. But it is clear that the league is not a partnership. This is evidenced by the fact that league members do not share profits and losses and that each retains control over basic decisions of strategy and managerial policy. Because the league is not a partnership, its claim of single entity status should be rejected. See, e.g., Hearings, supra note 8, at 369-71 (testimony of William R. Robertson, Commissioner, Los Angeles Coliseum Commission); id. at 405 (statement of Moses Lasky, Esq.), ("Anyone with [a] minimum of legal education knows that the essential element of a partnership is the sharing of profits and losses and the joint ownership of assets. The 28 clubs in the NFL are not joint owners of the assets of the clubs and they do not share profits.") See also Glick, supra note 17, at 59-60.

A careful review of the origins of the single entity theory in the sports cases indicates that application of the theory does not depend on a finding that the leagues are actually partnerships. Rather the contention is that the economic interdependency of leagues makes them loosely analogous to other types of entities that fall outside section 1. See, e.g., J. WEISTART \& C. LowELL, supra note 12 , at $699-701$.

Subsequent portions of this article give attention to the details of the NFL's structure which weigh both for and against the proposed analogy. See infra notes 152-71 and accompanying text.

80. The various professional leagues differ in the extent to which there is a sharing of revenues and a centralization of authority. Some features of the NBA, for example, involve distinctive partnership-like characteristics. There are now significant league-wide salary controls intended to limit the ability of teams to pursue their individual prerogatives in hiring players. An attempt has been made to equalize salary expenditures across the league so that clubs in weaker franchise locations spend roughly the same amount for players as those in lucrative markets. Although the present system admits of a number of exceptions, a cap on total salary expenditures is intended to remedy the imbalance that previously existed between strong and weak franchises. By the same token, though, a rule mandating a salary floor not far below the cap is intended to promote an equalized competition by requiring weaker franchises to pay salaries comparable to those of wealthier teams. See, e.g., N.Y. Times, Apr. 3, 1983, \& 5, at 2, col. 1; id. Apr. 1, 1983, at A19, cols. 1 \& 5. Because of the fioor, some franchises will be committed to a minimum salary budget well in excess of their ability to operate profitably on the basis of their individual receipts. Consequently, there is a plan for significant cross subsidization between clubs. Stronger clubs, in effect, will share profits with weaker ones and do so for the purpose of maintaining good opponents. See, e.g., id., Apr. 1, 1983, at A19, col. 5. The NFL would likely contend that it has chosen a different array of devices-particularly the equal sharing of lucrative television contracts-to achieve the ends sought by the NBA.

The NBA's equalization effort should increase the extent to which the league's co-venturers involve themselves in the management of individual franchises. If fellow owners provide significant financial subsidies to a club, they will likely not be indifferent about how the club is run. If the subsidized club makes foolish decisions in selecting players and setting salaries, some mechanism for oversight and intervention by other clubs will likely be devised. See Scorecard, SPORTS ILLus., Apr. 11,1983 , at 13 .

A question left substantially unexplored in Los Angeles Coliseum is the extent to which the clubs within the NFL have retained the authority to supervise the operation of individual franchises. As is discussed below, the majority assumed that the NFL clubs were highly autonomous in their managerial prerogatives. See infra notes 119-24 and accompanying text. Such a view, however, fails to give sufficient weight to the role of league rules in controlling managerial decisions that are disruptive of the league members' common interests. In addition, there is an inadequate accounting of the residual authority of the league to correct the misguided policies of an individual club. See infra note $125-33$ and accompanying text. 
At some still lower level of formal integration, the league's decisionmaking becomes subject to section 1 review but is saved from condemnation by a rule of reason justification based on the close intertwining of the participants' interests. In these cases, the compelling feature again is the cooperative character of the venture. Condemnation under section 1 is inappropriate because its premise of fostering competitive and unilateral behavior is inapplicable. As in the case of a fully-integrated venture, joint actions necessary to the success of the enterprise are not only protected but encouraged. ${ }^{81}$

The choice between the rule of reason and the single entity theory as the basis for correcting the result in Los Angeles Coliseum is thus a choice of degree and not of kind. If the facts pertaining to the NFL's internal operation show a significant degree of economic integration, then the single entity characterization would be appropriate. But even if one were not persuaded of the completeness of the participants' interrelationship, the rule of reason would still allow significant cooperative decisions to be removed from antitrust condemnation. In either event, there are aspects of each theory that warrant further attention.

\section{Reassessing the Substantive Rule of Reason Review}

What are the defects in the majority's rule of reason analysis? One error has already been indicated in a general way. The majority uses language suggesting that it believes competition will be enhanced if league controls are restrained. But the majority also gives recognition to league interests that make it doubtful that true competition between clubs will result. Thus there is an inherent muddling in the court's analysis. A more carefully reasoned appraisal would accept that a choice has to be made between the divergent approaches. And if the correct choice is made, the inherent noncompetitive character of internal league relationships will be given the predominant weight.

This approach is quite consistent with the general mandate that the rule of reason be used only to promote procompetitive outcomes. ${ }^{82}$ The Los Angeles Coliseum court is prepared to concede that the league can take steps to avoid serious competition between two franchises in a shared city ${ }^{83}$ and presumably must accept that there will be only a single

81. See NCAA v. Board of Regents, 104 S. Ct. 2948, 2961-62 (1984) (NCAA regulations enhance competition among members and enable a product to be marketed which might otherwise be unavailable).

82. See, e.g., National Soc'y of Professional Eng'rs v. United States, 435 U.S. 679, 691 (1978); see also supra notes 20-23 and accompanying text (discussion of rule of reason).

83. See supra note 56 and accompanying text. 
franchise in most cities. ${ }^{84}$ With the prospect of interclub competition virtually eliminated, it is not obvious that significant procompetitive virtues have been furthered by the decision. Indeed, any serious effort at listing those virtues would reveal the misdirected nature of the task.

Moreover, there is a strong argument to be made that giving the league discretion to allocate its franchises is itself procompetitive. Control of franchise location is part of the league's larger effort at effective market development. Viewed in this light, the controls are essentially enterprise-enhancing.

This is very close to an argument about the ancillarity of the league's restraint that was made by the league but apparently not fully understood by the court. ${ }^{85}$ The venerable case of Mitchel $v$. Reynolds, ${ }^{86}$ upholding a covenant not to compete by a seller of a business, provides the appropriate reference. While the covenant by definition limited competition at one level, it had a substantial, procompetitive justification. In the words of the Supreme Court in a recent passage specifically approving Mitchel v. Reynolds, the restriction had "the long-run benefit of enhancing the marketability of the business-and thereby providing incentives to develop such an enterprise." 87 Not every occasion for competition need be forced upon entrepreneurs. Enhancement of the basic enterprise is a proper goal. ${ }^{88}$ Thus, while owners of professional sports clubs would be competitors in some other types of industry structures (as with barnstorming teams), an authorization for cooperation enables a particular version of sports activity-a structured league race culminating in a national championship-to take place. ${ }^{89} \mathrm{~A}$ venture occurs that might not otherwise be possible and thus its internal controls are procompetitive.

84. See supra notes $49-58$ and accompanying text.

85. See Los Angeles Coliseum, 726 F.2d at 1395 . The majority reasons that an ancillary restraint, like any other, must be weighed in the procompetitive-anticompetitive balance. Thus, for the majority, the argument for ancillarity adds little, if anything, to the rule of reason. A different view is that ancillarity authorizes a court to focus on the nature of the enterprise being undertaken and ask how the particular restraint affects that enterprise in its efforts to compete against others. The majority's analysis places its primary emphases on intra, as opposed to interenterprise effects. See Bork, Ancillary Restraints and the Sherman Act, 15 ABA SEC. OF ANTITRUST L. REP. 211, 233 (1959) ("[t]he concept of business competition may be irrelevant as applied to the relationship between members of a league").

86. I P. Wms. 181, 24 Eng. Rep. 347 (K. B. 1711).

87. National Soc'y of Professional Eng'rs v. United States, 435 U.S. 679, 689 (1978).

88. See, e.g., NCAA v. Board of Regents, 104 S. Ct. 2948, 2961 (1984); Broadcast Music, Inc. v. CBS, 441 U.S. 1, 20 (1979); see also Bork, supro note 85, at 211.

89. For a further discussion of the distinctive features of a centrally-controlled league competition, see J. WEISTART \& C. Lowell, supra note 12, at 736-37. 
There is another perspective that should serve to underscore that franchise controls are necessary to maintain proper enterprise incentives and thus are enterprise-enhancing. The essential point is that the opportunity being allocated in a franchise decision is one that was created by the joint contributions of the co-venturers in the league and its disposition should be a matter of collective entrepreneurial prerogative. Especially important is a recognition of the right of the group to both secure a fair return for the opportunity relinquished and control the disposition of the resulting rewards. Without careful preservation of the co-venturers' interests in these matters, the incentives for the type of cooperative behavior essential to a league will be substantially diminished, if not destroyed. As Mitchel v. Reynolds suggests, the rule of reason does not require that legitimate business transactions be foregone.

This was the essential point of the hypothetical at the beginning of this article. The first part of the problem asked if the league would be permitted to charge a fair market value franchise fee to an outsider who purchased the right to operate the second Los Angeles team. Because the asset being sold is the product of the league members' collective effort, the answer presumably would be "yes."90 By contrast, though, the Los Angeles Coliseum case seems to hold that the same extraordinary opportunity must be given away free to an insider bold enough to claim it.

The justification for this result is hardly clear. Indeed, what seems more sound is the notion that in a franchised business, the acquisition of a franchise does not give an automatic and preemptive right to claim important corporate opportunities. The analogy that comes to mind involves a different organizational form but still seems apt for exploring the question of who can claim enterprise assets. Assume that $X$ purchases a McDonald's franchise and that the franchise operates on Locust Street in a Midwestern city. The franchise is quite successful over a several-year period. But then the state decides to build a limited access expressway that will siphon a good deal of the traffic off of Locust Street. In addi-

90. The debate over a somewhat analogous issue is pertinent here. Congress has given attention to the question of whether there ought not be more freedom of entry for new franchises in the major leagues. One proponent of freer entry, Representative Seiberling, recognized, however, that the presence of revenue-sharing opportunities creates a significant risk that free-riders will claim these revenue opportunities without making proportionate return contributions. See Hearings, supra notc 8, at 73-74 (statement of Rep. Seiberling). Because the corporate entity-the league-has made the right to share revenues valuable, it would seem that it should be allowed to receive a fair return if the right is diminished. See id. at 73 (testimony of Professor Gerald Scully). But if the "price" charged for the relinquished rignt approximates its present discounted value, it is likely that new entry will be deterred. See id. at 73 (testimony of Professor John C. Weistart).

This analysis is relevant to the present issue because franchise moves involve the appropriation of another form of corporate opportunity. If a valuable franchise location is relinquished by the league, presumably it can raise a similar claim to compensation. 
tion, there will be no access from the expressway anywhere near the McDonald's outlet.

$X$ is disturbed. He calculates that he can operate at a profit, but just barely. But then he hears that marketing surveys have indicated that the popularity of Myrtle Beach, South Carolina is such that a McDonald's franchise located on Ocean Boulevard in that city will be wildly successful. Must $X$ be given the Myrtle Beach location?

That would be a surprising result. The more correct view is that when $X$ accepted his franchise, he accepted an array of risks and limitations. $X$ surely has some right to make adjustments to improve his business, and, of course, the franchiser will want him to. It is quite another matter, however, to suggest that $X$ has the right to claim, cost free, the best corporate opportunity available at the particular time.

Some might suggest that the answer is not that the league can deny the franchise to the insider, but that the insider can be charged a fair price. If the analysis is taken to that point, there probably is relatively little controversy remaining. Once it is conceded that the co-venturers in the league can charge for a relinquished corporate opportunity, the inside suitor is likely to be discouraged. In effect, the insider would have to pay a double franchise fee, first at its initial entry and then later upon its relocation. A credit might be given for the franchise that was relinquished, but this is not a certain offset. In many locales, an operating franchise will be considerably more valuable than one that must start afresh.91 Moreover, the opportunity in the former location may be quickly lost to a competing venture.92

In terms of the rule of reason, the suggestion being made here is that the restraint involved in a league's control of the movements of existing

91. The value of the franchise opportunity in the insider's former city will likely be further diminished if the insider has already departed. Local fans are likely to view the move as an affront and may well be reluctant to embrace a new entrant. See supra note 25.

92. The movement of NFL franchises from Oakland and Baltimore was followed by the efforts of USFL clubs to establish themselves in these cities. The USFL presumably was attracted to the two markets because of their proven ability to support professional football clubs. On the other hand, both markets are small and the presence of a USFL club, even one that is only modestly successful, may mean that a new NFL club could not establish itself. If this was the outcome, the departing NFL club should receive no credit for the location it relinquished.

This analysis suggests a subsidiary point that would become important if the majority's analysis prevailed. A league ought to be empowered to provide for an orderly movement of franchises and thus, under some circumstances, should be able to insist that a club's prior location not be abandoned until a new entrant is found. The period of delay could be substantial, but delay seems to be warranted if the corporate entity is allowed to protect the value of its locations.

Moreover, it might be noted that it is not a significant additional step to conclude that the disgruntled owner should be required to relinquish ownership of his team in exchange for the right to purchase a new team in the new location. Such an outcome promotes league stability and satisfies the interests of fans in both the old and new location. See supra note 29. 
franchises should be seen as enterprise enhancing. Just as a former owner's agreement not to compete preserves the value of a business being sold, league control of franchise opportunity creates business assets that can be auctioned and sold to the benefit of all participants of the venture. ${ }^{93}$ Some choices of individual participants are deterred, but such a result is necessary if the other venturers are to have proper incentives to contribute to the careful development of the league's business.

The error of the majority's decision in Los Angeles Coliseum is in its assumption about the nature of the economic opportunity that is being claimed. An unstated premise of the case seems to be that the new franchise location is an open-market opportunity that may be claimed by the first entrepreneur - or more precisely, but less rationally, by the first entrepreneur with an existing franchise-who has the wherewithal to expropriate it. This approach misses the critical point about where, how, and at whose effort the opportunity arose. There is much more involved than simply the right to operate a professional football franchise in southern California. The opportunity to be claimed includes a right to identify with the NFL, to partake of its carefully nurtured preferred position among football fans, and to share in the considerable rewards of internal revenue-sharing. The proprietary nature of the opportunity should be apparent.

\section{A Critical Look at the Majority's Single ENTity ANALYSIS}

The persistent undercurrent in this analysis is that a sports league is a shared venture. While there is some room for individual creativity and impulse, the most successful leagues are those in which cooperation and common control predominate. The question naturally arises as to whether a sports league-in its franchising decisions specifically, or in its economic function generally-is not more appropriately treated as a unitary entity that lacks capacity to transgress the prohibitions of section 1 . Application of a single entity characterization would be a recognition that-at least as to some important functions-a league operates with such economic interdependence that it should be allowed to enjoy the economic freedom afforded other more traditional collections of capital, such as partnerships and corporations.

The majority in Los Angeles Coliseum was not unmindful of the single entity theory. Indeed, it addressed the issue squarely on both legal and factual grounds. ${ }^{94} \mathrm{~A}$ close review of its analysis, however, suggests

93. See supra notes $85-89$ and accompanying text.

94. Los Angeles Coliseum, 726 F.2d at 1387-90. 
that it did not adequately refute the appropriateness of treating the - league as a unitary entity. Indeed, the weaknesses in the court's attempted refutation serve only to reinforce the claim that the premises of section 1 do not apply to the activity involved in franchise location decisions.

The majority's analysis in Los Angeles Coliseum focuses on three justifications advanced by the district court for rejecting the single entity characterization. Each point of analysis is accepted by the majority. First, it is reasoned that a logical extension of the "single entity" argument would remove all league actions from section 1 scrutiny, but precedent, especially from the player restraint cases, is to the contrary. ${ }^{95}$ Second, in the view of the majority, other organizations "just as unitary" as a sports league have been found to violate section 1.96 Finally, it is contended that the argument in favor of treating the league as a single entity proceeded from a "false premise": $: 97$ that individual clubs have no value apart from their participation in the NFL. To the contrary, the majority held that "each team [is] an entity in large part distinct from the NFL."98

\section{A. The Independent Value of a Franchise.}

We will first review the last point, which requires the closest consideration of the factual aspects of a league's operation. The majority accepted the assertion of the district court that NFL clubs are "separate business entities whose products have an independent value." 99 This statement appears to contain conclusions on two different contentions: first, that as business entities individual clubs have economic characteristics sufficiently distinct and pervasive to warrant their separate treatment in the present controversy; and second, that the clubs produce products that are distinct and separable. We will treat these contentions in turn.

The majority's assertion about the independent value of the product of each NFL club appears to be based on a factual assumption that is at least highly debatable and probably erroneous. The district court criticized the NFL's argument for single entity status by suggesting that it included an erroneous assumption "that each club can produce football games only as an NFL member." 100 In the view of the district court, "[t] here is no conceptual reason why any NFL club could not decide to

\footnotetext{
95. Id. at 1388 .

96. Id.

97. Id.

98. Id. at 1390 .

99. Id. at 1389 (quoting Los Angeles Coliseum, 519 F. Supp. at 584).

100. Los Angeles Coliseum, 519 F. Supp. at 584 (emphasis in original).
} 
pull out and join a new league."101 On appeal, the majority embraced this analysis and extended it with the indirect suggestion that the independent value of an NFL club is proven by the fact that any NFL club could move to the rival United States Football League. ${ }^{102}$ Despite the agreement of the two courts on this point, it is far from clear that the owner of an NFL club could simply shift his players over to a rival league. And indeed if he could not-if the players could remain with the NFL-then the contention concerning a club's independent value weakens greatly, and perhaps dissipates entirely.

The doubtful premise of the courts' assertion is most clearly revealed if one asks whether a player under contract to an NFL club could object if the owner decided to switch leagues. Both courts apparently assume that the player has a contractual relationship only with the club and if the club is prepared to fulfill the terms of its promises, then the player must deliver his return performance even if in a different league. This assumption skips over a number of potentially critical points. At a general level, it can be observed that players frequently are not indifferent to where and for whom they play. A player may choose to play with the NFL because it has much more extensive television coverage, or because it plays during the traditional fall season, or simply because it is the more established professional league. Presumably, an actress who signed a contract to play the lead in My Fair Lady could not be compelled to appear in Oh! Calcutta! instead, even if the salary were the same. The traditional concern for respecting the expectations of the contracting parties would similarly suggest that a club's right to make a unilateral shift in its league affiliation is not a foregone conclusion. ${ }^{103}$

101. Id.

102. Los Angeles Coliseum, 726 F.2d at 1390.

103. The role of the law in insuring respect for the expectations of the parties is expressed in several different contract doctrines. In general, a party cannot be made to perform a contract different from that which he signed. Thus, contracts will be interpreted to have that meaning which is consistent with the intent of the parties at the time of signing, and it is that understanding that will be enforced. See 3 A. CoRBIN, Corbin on CONTRACTS $\S \S 532-545$ (1960). Moreover, the failure of the other side to deliver the return opportunity that was promised is usually a ground for termination. See 4 A. CORBIN, supra, at §§ 943-946; REsTATEMENT (SECOND) OF CONTRACTS $\S \S 241-242$ (1981).

In addition, efforts to transfer contract rights to another party or another setting can be resisted if the change will increase the promissor's risk, burdens, or opportunities. See 4 A. CoRBIN, supra, at §§ 865-868. See also J. WeISTART \& C. LowELL, supra note 12, at 291-98. While a true impossibility of performance or a substantial commercial frustration may alter the promisee's duty to deliver further performance, the law falls far short of embracing any notion that a change in perceived advantage allows the promisee to demand performance on different terms. Rather, the typical remedy where exigency arises is a termination of the agreement. See 6 A. CoRBIN, supra, at $\S \S 1353$ 1361; RESTATEMENT (SECOND) OF CONTRACTS $\$ \$ 261-272$ (1981). 
The NFL player will have other objections of a more specific nature. Most important are those that involve changes in the players' actual and potential compensation. An NFL player rightfully assumes that his participation in the league-funded pension plan is part of his compensation package. ${ }^{104}$ Indeed, an appraisal of the employee's rights that did not include this benefit would be critically incomplete. An owner's action terminating the player's rights under the league plan raises the serious prospect that the player would be excused from his own performance under the playing contract. ${ }^{105}$ In the same vein, most players would not lightly remove themselves from the provision of the NFL collective bargaining agreement specifying the minimum gross amount that league clubs will collectively spend on salaries. ${ }^{106}$ This provision was a major point in the settlement of the bitter 1982 strike by the players' union. ${ }^{107}$ Presumably individual players perceived that they would benefit by the guarantee that is provided.

This analysis could be carried through a variety of other terms in the documents governing the player's employment relationship, including those pertaining to player mobility, injury dispute resolution, and limitations on club-imposed discipline. ${ }^{108}$ That examination would reveal that each player develops substantial links with the NFL, and these acquire a status that is presumably entitled to protection under traditional contracts principles. It is important to emphasize what this analysis reveals. It appears that players are not highly mobile producers who can be switched between leagues at the sole discretion of an owner. Indeed, quite the opposite is suggested. Even though a player signs with

Recent writings in the law of contracts have renewed the concern for insuring that a contracting party receives the subjective value he sought from his contract. This emphasis on subjective value adds weight to the basic point made in the text. See Kronman, Specific Performance, 45 U. CH1. L. REV, 351, 354-76 (1978); Muris, The Costs of Freely Granting Specific Performance, 1982 DUKE L.J. 1053, 1054-55; Schwartz, The Case for Specific Performance, 89 YALE L.J. 271, 274 (1979).

104. Under the 1982 Collective Bargaining Agreement, the NFL clubs agreed to pay some $\$ 62.5$ million to the Bert Bell NFL Player Retirement Plan. The collective agreement also designated how benefits credits would be earned under the plan and specified the amount of disability payments to be made to a player. NFL-NFLPA Collective Bargaining Agreement Art. XXXIV, §§ 2, 8(a)(d) (1982).

105. A club's material breach of its contract normally excuses the obligation of the player to render the return performance. See J. WEISTART \& C. LowELL, supra note 12, at 279-82.

106. The clubs gave their guarantee that they would pay at least $\$ 1.28$ billion in player salaries for the four seasons between 1983 and 1986. Specific amounts are guaranteed for each season. If club expenditures in the four years do not reach the designated levels, the owner's Management Council is obligated to pay the players the balance according to a "downs-played" formula to be agreed upon by the union and management. NFL-NFLPA Collective BARGAining AgreEMENT app. $G$ (1982).

107. See N.Y. Times, Nov. 17, 1983, at 27, col. 4; id., Nov. 21, 1983, at E5, col. 4.

108. NFL-NFLPA Collective Bargaining AgREEMENT arts. XV, IX \& VI. 
the Los Angeles club or the Houston club, he develops deep and perhaps intractable links with the larger league that are entitled to legal respect.

Of equal importance is the fact that the ties between players and the league are neither haphazard nor incidental. Rather, they are specific manifestations of the commonality of the economic venture to which players attach themselves. ${ }^{109}$ Affiliation with this league rather than another is a partial reflection of the player's assessment of the league's success in marketing its joint product. Similarly, the player's appraisal of such important concerns as the league's short-term financial security and its ability to weather future market shifts may well be affected by how the league has accommodated its need for internal cooperation.

The majority's third justification for rejecting the single entity theory also rests on the fact that NFL clubs are maintained and operated as separate businesses. Each has different owners, each follows different management philosophies, and each has different levels of profitability. The league suggested that the importance of the clubs' separate corporate structures is diminished by the extensive revenue-sharing between clubs. This element, however, was insufficient to change the majority's basic view of the relationship among clubs: "[a]lthough a large portion of league revenue, approximately $90 \%$, is divided equally among the teams, profits and losses are not shared, a feature common to partnerships or other 'single entities." "110

The issue of how to treat the separateness of the various clubs within a league is not an easy one. The reasoning followed by the court has a certain cogency to it. There is, however, a literalness to the majority's analysis which is not required by existing precedents and which masks more subtle features of a sports league that are critical to the legal characterization. It is literally true that each club is separate, but it is also true that the partners in an accounting firm or law firm are separate legal

109. The analysis in the text focuses on claims that a player might raise to resist his transfer to another league. It can be noted that other league clubs may also have a right to object to such an attempted transfer. Another team may assert that any claim that the employer has to the player's services is contingent on those services being used in furtherance of the league enterprise. Such an argument has considerable force where the departing employer acquired its rights to the player in a recent league draft. Other clubs can properly assert that the draft was intended only to allocate negotiation rights for internal league purposes. Although other clubs refrained from negotiating with the player after the departing employer won its draft rights, they did so on the critical assumption that they would indirectly benefit from the increased on-the-field competition that would result from the player's remaining in the league. When that assumption is frustrated by the employee's threatened departure, other clubs should be allowed to insist that rights to the player be reassigned within the league according to a new draft or waiver procedure. Because the player typically consents in advance to intraleague assignments, his contract would be protected upon any other club's agreeing to pay the promised salary.

110. Los Angeles Coliseum, 726 F.2d at 1390. 
beings for some purposes. And the court is correct that net profits and net losses are not literally shared. But it is quite another matter to suggest that each NFL club is entirely responsible for its own profitability. Finally, while it is true that each club has management responsibilities and that the excitement generated by the league is frequently a product of the diverse management styles adopted by the franchises, it may not be correct to suggest that each club is a separate managerial entity. The league in fact reserves to itself extensive prerogatives, and in the final analysis these may well supersede the preferences of any individual league participant. ${ }^{111}$

It should be clear from existing precedents that the separate legal status of the participants in an economic venture does not preclude the possibility that their cooperative enterprise will be treated as a single unit for antitrust purposes. The concept here is as fundamental as the theory of the firm. Once we move to any enterprise more complex than a sole proprietorship, we are likely to find that there are multiple participants. Indeed, corporations, partnerships, and business trusts are frequently devices through which otherwise independent actors join their capital. Participants in such ventures need not relinquish their separate identities in order for their cooperative activities to be treated as a unitary venture under the antitrust laws. ${ }^{112}$

A curious feature of the majority opinion in Los Angeles Coliseum is the absence of an effective response to the major argument made in favor of treating a sports league as a single actor in its franchise decisionsthat the league has many characteristics of a partnership, at least in its franchising decisions. ${ }^{113}$ The partnership analogy reveals the limitations of the majority's emphasis on literalism. Partners in a partnership may

111. See Grauer, Recognition of the National Football League as a Single Entity Under Section 1 of the Sherman Act: Implications of the Consumer Welfare Model, $82 \mathrm{MicH}$. L. REV. 1, 27-35 (1983).

112. An argument has been made that if co-venturers accepted "the manifold legal, tax and business advantages of separate incorporation," then they should not be treated as a single entity for antitrust purposes. See Blecher \& Daniels, Professional Sports and the "Single Entity" Defense Under Section One of the Sherman Act, 4 WHITTlER L. REV. 217, 226 (1982). This view is clearly rejected in Copperweld Corp. v. Independence Tube Corp., 104 S. Ct. 2731, 2741-44 (1984).

Numerous authorities support the general notion that a partnership with corporate partners is valid. See Unif. PARTNership ACT $\S \S 2,6$, U.L.A. 12-13, 22 (1974); H. Reuschlein \& W. GREgORY, AgenCy AND PARTnership $\S 179$ (1979); Armstrong, Can Corporations be Partners?, 20 Bus. LAWYER 899, 899-900 (1965). Presumably, such an entity would also be recognized for antitrust purposes.

113. An analogy developed elsewhere is that which compares the league to a nationwide accounting partnership seeking to establish branch offices. If the firm rewards its partners on the basis of their individual productivity, it shares an important characteristic of a sports league. A refusal by the firm to authorize a branch office may limit a partner's economic advantage. It is not clear, though, that such a decision transgresses any important antitrust policies. See J. WEISTART \& C. 
take different legal forms; corporations can be partners of sole proprietors, for example. In addition, there may be a differentiated sharing of the rewards of the partnership venture, including an arrangement that compensates participants on the basis of their respective productivity and skill in executing the partnership task. Finally, the partnership need not exercise actual day-to-day control over the actions of the partners. Individual creativity and initiative can be encouraged. Indeed, in general partnership law, what ultimately seems to be important is the potential for joint control that is reserved by the partnership, not the actual control that is exercised over the constituent members. ${ }^{114}$

There is a good deal of value in avoiding literalism in the analysis of this issue. It is true that a sports league is not literally a partnership. And the analogy to a partnership cannot be applied four square. But the critical question is whether the sports league is sufficiently like a partnership to partake of the legal treatment afforded such an entity. ${ }^{115}$ Apart from mere assertion, the court's opinion makes no significant effort to establish the respects in which the subsidiary points of the partnership analogy are in error.

Certain aspects of the operation of a sports league warrant particular attention in this context. One is the matter of revenue-sharing. The court asserted that, while the vast majority of revenues are shared, profits and losses are not. This assertion, however, fails to fully recognize the economic effect of the league's cooperative behavior. Take the case of the NFL franchise that has turned in poor on-the-field performances for two or three years-readers can supply their own examples from among the several notorious instances that have occurred in recent years. Such a team has little television appeal, and its television exposure is often limited. But how much of the total NFL television revenues are paid to this unproductive club? By agreement of the NFL clubs, the poorly performing member receives an equal share. ${ }^{116}$ And who "earned" most of this revenue? Of course it is earned by the clubs that are more exciting and generate the substantial television audiences. In effect, then, "profits" attributable to the efforts of more productive members are directly shared with clubs that are making negative contributions. This same phenomenon can be viewed as a sharing of losses. If the club with a poor

LowELL, supra note 12, at 699-702. See also Grauer, supra note 111, at 2-7; Rothenberg \& Telleon, Restraints on Professional Athletes, 4 L.A. LAw. 35 (1981).

114. See, e.g., H. ReuSChLEIN \& W. GREGORY, supra note 112 , at $\S \S 13-15,23,184,187,194-$ 195.

115. See supra notes $79-80$ and accompanying text.

116. For a more detailed explanatiou of the division of television receipts within the NFL, see Hearings, supra note 8, at 253-56 (written response of NFL Commissioner Pete Rozelle to questions from Representative Rodino, Chairman, Committee on the Judiciary). 
performance were entitled only to revenues that it generated solely through its own performance, it would likely produce a balance sheet loss, for even as successful as the NFL has been in general, fans have not shown themselves to be inclined to make losers separately profitable. But within the league, what would otherwise be operating losses often become profits because of an infusion of shared receipts.

When the focus of the analysis is broadened to include other forms of cooperative behavior, the significance of the majority's emphasis on the separate status of each team is further diluted. For example, the sharing of gate receipts dulls considerably any suggestion that individual clubs capture the rewards of skillful management and promotion of their specific team. Who benefits from a successful local advertising campaign that fills a cavernous stadium? With a 60-40 revenue split, the beneficiaries include all teams who visit there. And who benefits if a perceptive management makes a mediocre team competitive? Again, the division of gate and television receipts insures that the rewards of adeptness are not hoarded.

Frequently overlooked is the fact that many operational rules of the league are actually devices for sharing risks and wealth. Properly viewed, a system for allocating new talent by a draft is largely a method to provide cross subsidization between clubs. ${ }^{117}$ Wealthier, more successful teams that would otherwise have a superior opportunity to sign the best new talent forego that right and, through the device of the league's draft rules, reallocate these important assets to less successful franchises. The subsidy, if successful, will avoid the recurrence of negative operating revenues for a weak franchise. The draft rights even become a crude form of money when they are included as part of a larger trade package. ${ }^{118}$ Thus, the subsidy may be cashable immediately and affect the seller's balance sheet in a very tangible way. The rewards of success are not as highly individualized as the court suggests, and intraleague sharing has a significant effect on relative profitability.

The majority opinion may have also moved too quickly through the question of the degree of managerial prerogative retained by individual

117. See J. WEISTART \& C. LoWELL, supra note 12 , at 544-45, 594-95.

118. Indeed, economists have complained about this cross-subsidization aspect of player restraints. It was contended that the traditional restraints denied to players the opportunity to receive their fair market value in contract negotiations. Once a club obtained rights to a player, it could sell the contract to another club and claim to itself the difference between the player's contract salary and his free market price. See H. DeMMERT, supra note 17, at 31-39; Canes, The Social Benefits of Restrictions on Team Quality, in GOVERNMENT AND THE SPORTS BUS1NESS, supra note 17, at 81; Quirk \& El Horidi, The Economic Theory of a Sports League, in id. at 33. In most leagues, recent changes in the player restraint arrangements have diminished significantly the contract-market price differential. 
clubs. In the court's view, "[t]he disparity in profits [among clubs] can be attributed to independent management policies regarding coaches, players, management personnel, ticket prices, concessions, luxury box seats, as well as franchise location . . . ."119 As just noted, however, the league has already made a significant decision which refutes any suggestion that astute franchise managers are allowed to capture all of the economic rewards of their actions. The league has decided that the returns from successful local management, both those returns coming through the gate and those that result from television appearances, must be shared. It is true that the producers of the successful teams generally receive the greatest rewards, but this is not wholly different from the typical professional partnership which gives recognition to individual productivity. There is therefore some uncertainty as to exactly what the court uncovered with its observation about a disparity in profits. Did it discover the ingredient that proves the separateness of individual clubs, or did it merely see the consequences of an internal reward system of a firm that wants to insure that the incentives for success are not muted?

To answer this question, the majority should have carefully assessed the range of potential managerial control that the league has reserved to itself. Interestingly, the opinion is silent on this critical question. Indeed, as presented, there is a question-begging quality to the majority's analysis: it is suggested that the task before us is to ascertain how the antitrust laws will affect league decisionmaking; that depends in part on the nature of the entity we have before us; that will be defined in part by the degree of control that the league can exercise over management policies; but that, of course, is precisely the question that we set out to answer. The majority's opinion heartedly embraces this circularity when it suggests that "individual management policies regarding . . . franchise location" 120 are evidence that the entities involved are sufficiently independent to require close antitrust scrutiny of their collective actions, including league decisions on franchise location. But whether a club can claim such independence is precisely the issue at hand.

It would seem preferable to start with an assessment of the managerial prerogatives that leagues-that is, league members acting collectively-have reserved to themselves. That should tell us a good deal about how closely a league comes to replicating the characteristics of a single firm. On that point, other antitrust precedents seem to make clear that unitary action may be found even when individual components are

119. Los Angeles Coliseum, 726 F.2d at 1390.

120. Id. 
left to conduct their day-to-day affairs free from centralized control. ${ }^{121}$ - The critical ingredient seems to be not the completeness of actual control, but rather the potential for ultimate control by a dominant unit. 122

In the case of a sports league, that potential for league control has historically been presumed to be virtually complete. Members of a league acting collectively have assumed that they had authority to determine the location of league franchises, how these franchises will be owned, the broadcasting arrangements that the league will pursue, how revenues will be divided, and even the terms upon which clubs contract with players. ${ }^{123}$ A consideration of the types of decisions that could have been made, but were not, underscores this point. Could the NFL have left the home team with only forty percent of the gate receipts rather than sixty percent? ${ }^{124}$ Could the league have included a buy-out provision to rid its franchises of incompetent management? Again, absent the "rule" first announced in the insiant case, the answer was assumed to be "yes." And the reason for this was the economic interdependence of the actors within the league. There are very good business reasons why a league's clubs have a keen interest in the management of individual franchises and the manner in which revenues are divided.

The prospect of wide-ranging, and indeed ultimate, league control rests on more than mere assertion. One would want to think carefully about the significance of Charles $O$. Finley \& Co. v. Kuhn $n^{125}$ before embracing the majority's claims as to the sanctity of the management decisions of individual club owners. Finley's Oakland A's had won the World Series in 1972, 1973 and 1974. In 1976, Finley conducted the sports equivalent of a liquidation sale: he arranged to sell or trade the contracts of several star players. ${ }^{126}$ The reason for the action was somewhat in dispute, but the effect was unmistakable-a team that had prevailed in the carefully structured league competition was being

121. See Copperweld Corp. v. Independence Tube Corp., 104 S. Ct. 2731, 2733 (1984).

122. In Copperweld Corp. v. Independence Tube Corp., 104 S. Ct. 2731 (1984), the Supreme Court reversed prior precedent and held that a parent corporation and a wholly-owned subsidiary were incapable of engaging in a conspiracy under section 1 of the Sherman Act. The Court did not think that the degree of actual day-to-day control exercised by the parent was determinative: "They share a common purpose whether or not the parent keeps a tight rein over the subsidiary; the parent may assert full control at any moment if the subsidiary fails to act in the parent's best interests." Id. at 2742.

123. See supra notes $35-40$ and accompanying text.

124. Cf. NCAA v. Board of Regents, 104 S. Ct. 2948, 2974 (1984) (White, J., dissenting) (noting that the majority does not limit the NCAA's right to force revenue sharing). It should also be noted that the NBA has apparently assumed that it has the right to go beyond a mere sharing of gate receipts to require gross subsidies between teams. See supra note 80 and accompanying text.

125. 569 F.2d 527 (7th Cir. 1978).

126. See N.Y. Times, June 19, 1976, at 1, col. 2. 
dismembered. The Commissioner of baseball blocked the action under a provision of the league constitution that empowered him to prevent actions detrimental to the best interests of baseball. ${ }^{127}$ The Commissioner was, of course, exercising power that had been delegated by the various league participants.

Under the division of authority assumed by the majority in Los Angeles Coliseum, the Oakland baseball franchise might be thought to have the right to set "independent management policies regarding . . . players." 128 The courts that reviewed Finley's complaints about the Commissioner's interference, however, disagreed, and the league's assertion of authority was upheld. The case is interesting for the present discussion because it avoids the inherent circularity of the antitrust analysis in Los Angeles Coliseum. Because baseball, at least in the activities in question in Charles O. Finley \& Co. v. Kuhn, is exempt from the antitrust laws, ${ }^{129}$ the analysis proceeded on other private and public law bases. ${ }^{130}$ In the end, however, no legal principle was found that limited this exercise of centralized league control. Even though the managerial decision being countered involved players directly under contract with the plaintiff's club, and even though the decision was intimately involved in the local owner's efforts to maximize his economic advantage, the exercise of ultimate control by the league was found to be proper.131 Other decisions involving the baseball Commissioner's authority to discipline league clubs and their owners are similarly expansive. ${ }^{132}$ There are few hints of

127. Major League Agreement, art. 1, § 2: "[t]he functions of the Commissioner shall be . . . to investigate. . . any act, transaction or practice . . . not in the best interests of the national game of Baseball" and "to determine ... what preventive, remedial, or punitive action is appropriate."

128. The quoted language is from Los Angeles Coliseum, 726 F.2d at 1390.

129. See, e.g., Flood v. Kuhn, 407 U.S. 258 (1972).

130. Plaintiff Finley's complaint asserted seven different causes of action, ranging from improper interference with contract to a denial of constitutional due process and equal protection. See Charles O. Finley \& Co., 569 F.2d at 531.

131. The Commissioner gave three reasons for his action. Two are particularly germane to the present discussion because they are unmistakably founded on the notion that the league has general collective interests that transcend the right of the club to manage its players, even though player contracts are assets that the club ostensibly owns separately. Commissioner Kuhn asserted that the sale of the star players would not only debilitate the Oakland franchise, but would also upset the competitive balance within the league by further strengthening already affluent clubs. Hence, in the league's view, it had an ongoing interest in the relationship between the Oakland club and its fans. In addition, the club's control of the players affected the economic interests of other owners. Again, the fact that the club "owned" the player's contracts was not regarded as a sufficient reason to give the club control of their disposition. See Charles O. Finley \& Co., 569 F.2d at 531. The court indicated that it found ample authority for the power that was exercised. Id. at 538-39.

132. See, e.g., Atlanta Nat'l League Baseball Club, Inc. v. Kuhn, 432 F. Supp. 1213, 1216-17 (N.D. Ga. 1977) (upholding then Commissioner Bowie Kuhn's suspension of Atlanta Braves owner Ted Turner for violating Major League Rules as well as provisions of the collective bargaining agree- 
the sort of pervasive local powers that are declared to exist by the majority in Los Angeles Coliseum.

Again, the problem here seems to be one of the proper characterization to be applied to observed facts. The majority observed that some individual prerogatives were exercised by the separate NFL clubs and that these decisions had a differential impact on economic return. This led the majority to conclude that the clubs were separate entities. A deeper probing, however, would have cast doubt on this conclusion. It is true that individual effort is rewarded in the NFL and that the league product is attractive because clubs make separate strategic judgments on the development of their product. ${ }^{133}$ But there is much more to the nature of the league's operation. League members have historically ceded significant authority to their collective instrumentality. There are actual examples of broad exercises of league authority and legal bases to support claims of rather pervasive retained but unexercised prerogatives. It is these powers that should provide the perspective for assessing the discretion that individual franchises exercise. When this assessment is made, the integrated, cooperative character of the league's operation is difficult to dismiss.

\section{B. Other Entities "Just as Unitary."}

The Los Angeles Coliseum court's analysis of the antitrust treatment afforded other cooperative entities reveals additional significant flaws in the majority's reasoning. A second justification advanced by the court for denying the league's single entity analogy is that other entities "just as unitary" have been found to violate the antitrust laws. ${ }^{134}$ It is at this juncture that the opinion makes its most earnest effort to bring its rejection of the single entity argument within the ambit of major Supreme Court precedents. The majority's primary analytical tool is the analogy: it asserts that the economic organization of the NFL is like that of other entities whose susceptability to section 1 review has been established by the Supreme Court. Several cases are cited, but the court relies most

ment with the players); Milwaukee American Ass'n v. Landis, 49 F.2d 298, 300 (N.D. Ill. 1931) (upholding Commissioner's action of disapproving an option contract between the St. Louis and Milwaukee baseball clubs). See generally J. WeISTART \& C. LowELL, supra note 12, at 315-18.

133. The Second Circuit Court of Appeals in North American Soccer League v. National Football League, 670 F.2d 1249, 125 I (2d Cir. 1982), explicitly recognized that the practice of separate ownership of franchises has a substantial marketing justification. Such ownership was seen as "desirable in order to convince the public of the honesty of the competition." The court went on to note, however, that a somewhat contradictory goal-relative equality of playing strength among competing clubs-must also be achieved. Id.

134. Los Angeles Coliseum, 726 F.2d at 1388 (quoting Los Angeles Coliseum, 519 F. Supp. at 583). 
heavily on Associated Press v. United States ${ }^{135}$ and United States v. Sealy, Inc. ${ }^{136}$ However, a critical examination calls into question the appropriateness of using these precedents.

As has already been noted, a central point in the league's claim of unitary status is that cooperation is a necessity and economic interdependency a reality. Indeed, most observers accept that no single team can produce a football game, and no single team can be indifferent about the quality of its competition. ${ }^{137}$ In addition, the economic fortunes of one team can be greatly affected by those of other league members. ${ }^{138}$ Since franchising decisions can have a significant effect on the financial return of both the individual club and the league in general, they are an important, and sometimes critical, mechanism for insuring that economic relationships remain in balance. The majority in Los Angeles Coliseum makes the bold assertion that in other settings the necessity of cooperation has not precluded the application of section $1 .{ }^{139}$ The majority then mentions Associated Press and states that in Associated Press "the Supreme Court rejected the assertion that the AP was immune from section 1 because it was a necessary cooperative of independent newspapers which produced a product its individual members could not." 140

There is a fundamental difficulty with this characterization. The need for cooperation in Associated Press is quite different from that claimed by a sports league. The Associated Press is a collection of newspapers that gather news in their respective local markets and feed the stories into a national network where they are used by other member papers. The cooperative effort thus enables relatively small local papers to cover events from across the nation. It would be very expensive for individual papers to provide nationwide coverage, and for many the cost would be prohibitive. This fact led concurring Justice Frankfurter, but not the full majority of the Supreme Court, to say the AP gathered and distributed news items that the individual members "cannot collect single-handed, and which require their pooled resources." 141

But this pooling is "required" in a much different sense than is the sharing involved in the operation of a football league. In Associated Press, no one contended that it was economically impossible for a single paper to have a national news network or that the financial fortunes of

135. 326 U.S. 1 (1945).

136. 388 U.S. 350 (1967).

137. See supra notes $17 \& 62$ and accompanying text.

138. See supra notes $17-18$ and accompanying text.

139. Los Angeles Coliseum, 726 F.2d at 1389.

140. Id.

141. Associated Press, 326 U.S. at 26 (Frankfurter, J., concurring). 
the various providers were irrevocably tied together. Indeed, later developments in the newspaper industry have established that expansive coverage by a single publisher is quite possible. ${ }^{142}$ Hence, the collective effort of the Associated Press was largely a device to make newsgathering more convenient. The claim of clubs within a sports league, however, is a claim of true necessity. No product can result without cooperation,and perhaps more to the point, the entities involved are inherently interdependent in a financial sense. ${ }^{143}$ While newsgatherers can be relatively indifferent as to whether their fellow venturers are poor or wealthy, effi-

142. USA Today, The Wall Street Journal, and to some extent The New York Times provide useful contrasts to the system offered by the Associated Press.

143. It is important to note that there is a difference between the need for cooperation on the one hand, and financial interdependence on the other. The Supreme Court's decision in NCAA v. Board of Regents, $104 \mathrm{~S}$. Ct. 2948 (1984), bears the seeds of significant potential confusion on this point. In characterizing the NCAA, the Court draws an analogy to a sports league. Id. at 2960-61. The Court identifies the inherent need for cooperation in setting schedules and defining rules of play as reasons why a rule of reason analysis, rather than a per se approach, is appropriate for analyzing the antitrust status of both sports groups. The Court also notes that the participants have a common interest in promoting their sports product.

It is true that professional sports leagues, the NCAA, and other sports associations such as the Professional Golfers Association are similar in the extent to which they must cooperate to produce and promote their respective products. Subsequent footnote references in the NCAA opinion, however, suggest that the majority believes that the NCAA and a professional sports league are legally analogous in other respects as well. Id. at $2961 \mathrm{n} .24,2962 \mathrm{n} .28,2964 \mathrm{n} .35$. There is an implication that the $N C A A$ opinion provides the framework for analyzing the antitrust problems of league organizations. This approach fails to take account of the feature that provides a critical distinction between the two types of governing entities-the financial interdependence of the participants. As suggested in this article, such interdependence is a fundamental feature of a professional sports league that operates a traditional unified sports competition. Contrary to the implications of the NCAA decision, however, there is not economic interdependence among NCAA teams. The number of entrants is so large-even within Division I-that worthy opponents will emerge without crosssubsidization. In short, good teams can find lively competition even without having to finance it. In addition, there are forces in college sports that deter the stockpiling of talent by a few teams and insure a relatively constant redistribution of promising incoming players. The rules limiting eligibility to four years and those which, in effect, standardize the amount of aid that can be paid, operate to permit the athletic fortunes of teams to change over time. This is quite unlike the situation that exists in a professional sports league where there is a danger that a team could otherwise hoard talent, and where the ability to do so varies significantly based on the relative profitability of franchise locations. See J. WEISTART \& C. LowELL, supra note 12, at 595-97. In the league setting, clubs have found it necessary to adopt equalizing devices, such as revenue sharing plans, mobility restraints, and the like.

The difference between a governance structure based on cooperation and one based on interdependence is quite important for antitrust purposes. The need for cooperation may only serve to move such a structure within the rule of reason and provide a potential justification to be examined. True economic interdependence, however, changes the basic character of the organization. As suggested in later paragraphs, see infra notes 174-78 and accompanying text, a group of actors that is truly interdependent and that operates in an integrated fashion begins to look like a separate firm, the type of entity whose governance decisions fall outside the scope of section 1.

The difference between a venture that is interdependent and one that is merely cooperative apparently was not fully settled in the Los Angeles Coliseum case. In their brief opposing the NFL's petition for certiorari, the Raiders gave the following appraisal: 
cient or mismanaged, these are fundamental concerns to a group of clubs seeking to maximize fan interest in both individual events and championship games. Thus, Associated Press seems to have involved an issuecollective action undertaken for economic convenience-that does not arise in the sports context.

The court also placed considerable reliance on United States $v$. Sealy, Inc. ${ }^{144}$ Indeed, the majority stated that it perceived the case to be "closely on point."145 Sealy involved something of a joint venture. Because the Supreme Court found the organization to be subject to the antitrust laws, the clear implication for the Los Angeles Coliseum majority is that the Supreme Court would reach a similar conclusion were it to examine the relationship of the clubs within the NFL. Once again, though, there are weaknesses in the attempted analogy.

Sealy involved the cooperative use of a leading brand name in bedding. The Sealy company owned the right to the Sealy name and licensed its use by various manufacturers. Although at one time it was independently owned, the Sealy company eventually came to be owned and controlled by the respective licensees. The licensees encountered antitrust difficulties when they agreed to abide by exclusive territorial allocations. The Supreme Court affirmed that these attempted market divisions were illegal.

There are two problems with the use of this case by the majority in Los Angeles Coliseum. The majority fails to acknowledge the controversy surrounding the Sealy decision. There is authority for the view that Sealy proceeds from a faulty economic premise to the extent that it raises impediments to the licensees' successful marketing of the Sealy

\footnotetext{
NFL paints the individual characteristics of the professional sports business as different from a variety of other businesses. Its argument both starts and ends with the premise that there is a significance of a sports 'league.' [sic] The premise has never been disputed. Professional football is a species of business in which numerous separate entities engage, each for profit, and by the nature of the business the clubs must play each other. To the end of arranging the games and administering the playing against each other, cooperative action is necessary. The significance of a league is that it is the apparatus to administer the playing of games. Within that context and for that limited purpose, agreement and cooperation can be reasonable. But insofar as cooperative action infringes upon the freedom of competition, the law is violated.
}

Brief of Respondent Los Angeles Raiders in Opposition to Petition of National Football League for Writ of Certiorari at 9, National Football League v. Oakland Raiders, Ltd., cert. denied, 105 S. Ct. 397 (1984) (emphasis in original). The perspective expressed here is considerably different from that taken by most commentators. Most authorities have seen a need for interaction among clubs that extends well beyond "arranging the games and administering the playing against each other." See supra notes 62-63 and accompanying text.

144. 388 U.S. 350 (1967).

145. Los Angeles Coliseum, 726 F.2d at 1389. 
brand in competition with other brands of bedding. ${ }^{146}$ There is doubt about whether the decision can be read expansively, especially in an era when a reconstituted Supreme Court has indicated a willingness to evaluate substance and minimize organizational form in antitrust analysis. ${ }^{147}$ At a minimum, the case hardly warrants an unqualified application. ${ }^{148}$

In addition, there are grounds to doubt the attempted analogy between the Sealy arrangement and a professional sports league. The point here is that made with reference to Associated Press. ${ }^{149}$ The arrangement among the licensees in Sealy may have been convenient, but it can hardly be said to have been the product of necessity. Notably Jacking was any substantial basis to suggest that the bedding manufacturers endured an unavoidable economic interdependence. ${ }^{150}$ Indeed, the opposite seems to. have been true. Beyond a minimal level of profitability that assured adequate product quality and market saturation, the relative fortunes and efficiencies of the respective participants were not a concern. In fact, the demise of some co-participants might actually have been welcomed as this would leave a demand for Sealy bedding that others could satisfy. It is quite conceivable that some licensees harbored secret plans to gain control of the brand, realizing that no principle of economics would require the indefinite joint production of Sealy bedding. ${ }^{151}$

In the end, the majority's second reason for rejecting the single entity argument fails. The difficulty is that the attempted analogies are stretched too far. While we do find Supreme Court cases that consider cooperative ventures, it is not true that the entities involved are "just as unitary." In fact, the arguments made by a sports league are unique and

146. See, e.g., Liebler, Book Review, 66 CALIF. L. Rev. 1317, 1333-41 (1978). See also E. GELLHORN, supra note 13, at 187-88.

147. See, e.g., Copperweld Corp. v. Independence Tube Corp., 104 S. Ct. 2731, 2741-42 (1984).

148. The Supreme Court's more recent Broadcast Music and NCAA decisions would seem to require that an inquiry be made as to whether the restraints in Sealy could be justified as enterpriseenhancing. See NCAA v. Board of Regents, 104 S. Ct. 2948, $2961-62$ (1984); Broadcast Music, Inc. v. CBS, 441 U.S. 1, 18-23 (1979).

149. 326 U.S. 1 (1945); see supra notes $137-43$ and accompanying text.

150. The difference between the sports industry and the setting of the Sealy case is suggested by public policy issues that have appeared in the sports context. For example, it has been proposed that revenue sharing among clubs should be compelled by statute. See Noll, Alternatives in Sports Policy, in GOVERNMENT AND THE SPORTS BusINESS, supra note 17, at 411,414 . Such a provision, mandating a minimum 70-30 split of gate proceeds, was endorsed by the Senate Judiciary Committee in its recommendations for legislation to govern the merger between the NBA and the American Basketball Association (ABA). See S. ReP. No. 1151, 92d Cong., 2d Sess. 1, 4 (1972); see also Carlson, The Business of Professional Sports: A Reexamination in Progress, 18 N.Y.L.F. 915,931 (1973). Such proposals have as their premise that cross-subsidization is essential for the efficient operation of a sports league. It is quite unlikely, however, that a similar contention could be successfully put forth in the Sealy context.

151. Further elaboration on the differences between the production of sports products and other commodities and services can be found in J. MarkHAM \& P. TEPLITZ, supra note 39, at 19-25. 
require a much more careful probing of the dividing line in antitrust law between unitary and conspiratorial activity.

\section{A True "Entity" Exemption?}

The majority's argument that treating the league as a single entity would place the league beyond the reach of section 1 prompts a useful question about the nature of the single entity defense itself: is it a doctrine that can only immunize "entities" for antitrust purposes, or is it an expression of antitrust policy that can be applied to selected entity activity? The majority, however, saw no reason to search for great subtlety in the league's contention that it was analogous to a partnership and should be so treated for antitrust purposes. For the majority, the proffered argument could be quickly rejected because, carried to its logical extreme, it would produce an absurd result. The result that the majority in Los Angeles Coliseum seeks to eschew is the complete immunization of the NFL from section 1 liability. In the court's view, not only would this be absurd, it is also fanciful, for several different courts have found section 1 violations in other NFL rules. The principal cases mentioned by the court are Kapp v. National Football League, ${ }^{152}$ Mackey v. National Football League, ${ }^{153}$ and Smith v. Pro Football, Inc. ${ }^{154}$ all decisions striking down various restraints on player mobility. ${ }^{155}$

There is a great plausibility in the court's reasoning on this point. The proffered defense is, after all, one that inquires into the general nature of the entity and it is one that seeks to classify the entity's status under the antitrust laws. If the entity is found to be outside the concerns of section 1, then presumably it is free of those strictures in all of its functions. Stated another way, a partnership is a partnership. If we decide that the league is in fact a collective entity, then presumably that characterization should apply in hiring decisions, marketing decisions, or internal agreements to divide revenue. On the other hand, if in other cases we have found that the accumulation of capital retained a basic duality, then that characterization ought to apply over a range of activities. ${ }^{156}$

152. 390 F. Supp. 73, 86 (N.D. Cal. 1974), affd, 586 F.2d 644 (9th Cir. 1978), cert. denied, 441 U.S. 907 (1979).

153. 543 F.2d 606, 623 (8th Cir. 1976).

154. 593 F.2d 1173, 1183-89 (D.C. Cir. 1978).

155. These cases are discussed in J. WeistaRT \& C. Lowell, supra note 12, at 603-17 \& Supp.

156. This seems to have been the approach taken by North American Soccer League v. National Football League, 670 F.2d 1249, 1256-58 (2d Cir. 1982). But see Mid-South Grizzlies v. National Football League, 550 F. Supp. 558, 560 (E.D. Pa. 1982) (while purporting not to decide single entity question, court allows league to exercise partnership-like control of membership), aff'd on other grounds, 720 F.2d 772 (3d Cir. 1983). 
There is, however, another view. The single entity defense can properly be used less as a gauge for pigeonholing entities and more as a means of expressing the policy conclusion that in certain unusual accumulations of capital, some basic business decisions ought to be removed from antitrust scrutiny because the relationships involved are close to those that earn antitrust immunity in more traditional settings. The difference is one between the court's assumption that single entity status must be earned by a top-to-bottom integration of the firm in question, and the view that entity-like behavior-when premised on economic necessityis sufficient to call forth the policies that prompt the different treatment of separate entities. ${ }^{157}$ In appraising the second view, it is relevant to ask whether there are any principled divisions that can be established to confine the reach of the single entity analogy. The majority's concern, of course, is that there are not. Yet, its opinion does relatively little probing of the point.

Some potential limitations do suggest themselves, and it does not seem inevitable that a sports league would be treated as a single entity for all decisions that it makes in connection with its operation. One could imagine, for example, that the antitrust liability of the league might vary depending on whether the clubs involved were buying uniforms, assigning players, or allocating franchises. It should be clear that the clubs within a league involve themselves in a variety of different markets and take actions which affect third parties who have varying degrees of closeness to the league's management. The contrast between suppliers of uniforms, players, and fellow club owners is suggestive of the range of activities that might be examined. Such an analysis was an important part of the appraisal offered by the dissenting opinion in Los Angeles Coliseum. Judge Williams perceived that a rough distinction could be drawn between the league's end product, or "downstream output," and its inputs or "upstream flow."158 The former is its product of professional football and the latter is its relationship with players and other suppliers. For Judge Williams, there was no problem of unintended results because again, there was a point at which a principled distinction could be drawn to confine the implications of the single entity theory. ${ }^{159}$

The real concern underlying the search for the limits of the single entity analogy seems to be that discussed earlier-the question of the extent to which clubs within a league can be viewed as competitors. The majority thought that it perceived a significant potential for competition

157. Those policies are discussed infra notes 176-78 and accompanying text.

158. Los Angeles Coliseum, 726 F.2d at 1406 (Williams, J., dissenting).

159. See also J. WeistaRT \& C. LowelL, supra note 12, at 702. 
between the Raiders and the Rams. One who believes this to be so is likely to be skeptical about any contention that these "competitors" should really be treated as one entity. But as previously suggested, the court may have made a fundamental error in its assumptions about increased competition. The local competition that may occur will hardly be robust and, indeed, if business planning were a science, would not occur at all. ${ }^{160}$ In addition, the majority's premise fails to deal with the fact that most members of the league compete with neither the Raiders nor the Rams, and most face no serious prospect of competition from another NFL club because they are located in single-team cities. ${ }^{161}$

A different view of intraleague "competition" provides the basis for reasoning back to the nature of the entity behavior involved. If the essential ingredients of the activity-here protecting corporate opportunities, controlling errant economic impulses, and developing a national market-are mainly related to the cooperative, noncompetitive characteristics of the league, then it seems appropriate to afford the venture the same range for creativity that is enjoyed by traditional entities with similar attributes. In other functions the league will be treated differently. The claim of an inherent cooperative character will not always be available. But where the league is functioning as an integrated unit, its unitary nature should be both respected and encouraged.

The issue of how literally to apply the single entity concept is somewhat clarified by developments with respect to the intra-enterprise conspiracy doctrine that occurred after Los Angeles Coliseum. The majority in Los Angeles Coliseum used its concern for the breadth of immunity that the single entity defense would impart as the occasion to discuss the law applicable to intra-enterprise conspiracies. The majority drew some support for its rejection of the NFL's single entity defense from Supreme Court decisions that held that separately incorporated entities could violate section 1 even if they were commonly owned and controlled. The majority's implicit point was that if a wholly-owned subsidiary is to be treated as a separate entity for section 1 purposes, then surely the constituent clubs of a league, which had even more clearly discernible characteristics of independence, should not be treated more favorably. Four months after the Los Angeles Coliseum opinion was issued, the Supreme Court repudiated the traditional intra-enterprise doctrine in Copperweld Corp. v. Independence Tube Corp. ${ }^{162}$ and overturned the precedents on which it was based. The Court specifically held that a parent corporation

160. See supra notes $45-50$ and accompanying text.

161. See supra notes $57-58$ and accompanying text.

162. 104 S. Ct. 2731 (1984). See supra notes $121-22$ and accompanying text. 
and its wholly-owned subsidiary lacked the requisite duality to justify application of section 1 prohibitions. The force of the point made by the majority in Los Angeles Coliseum is thereby lost. More important, however, are the implications of the rationale used by the Supreme Court in Copperweld.

Copperweld contains an interesting essay on why the antitrust laws draw such a sharp distinction between " concerted and independent action." "163 The former is treated under section 1 , while the latter is the object of section 2's concern for monopolization. And, in the words of the Court, "concerted activity subject to [section] 1 is judged more sternly than unilateral activity under [section] 2."164 The reason for treating concerted activity under a more exacting standard is that such behavior "deprives the marketplace of the independent centers of decisionmaking that competition assumes." 165 On the other hand, section 2 is more lenient because it seeks to encourage creativity and prerogative. ${ }^{166}$ In short, legal restraints on single firm activity are purposely drawn more narrowly in order to allow the actor maximum opportunity to find his market advantage.

In elaborating on the evils of conspiracies, the Copperweld Court uses various phrases that further suggest the state of affairs subject to condemnation under section 1. For example, the Court notes that in improper conspiracies there is a joinder by entities "that previously purused their own interests separately."167 In addition, the Court on at least three occasions suggests that conspiracies represent a "sudden joining together" of otherwise independent economic forces. ${ }^{168}$ The concept embodied in this phrase also partially explains why joint action between a parent corporation and its wholly-owned subsidiary should be viewed as not involving a section 1 conspiracy. In that case, "there is no sudden joining of economic resources that had previously served different interests." 169

The concept that is conveyed has relevance for a professional sports league. The clubs within a league never were wholly independent actors. And there is no "sudden joining" of interests that previously were separate. Indeed, the process through which sports leagues are formed is in-

163. Copperweld, 104 S. Ct. at 2740 (quoting Monsanto Co. v. Spray-Rite Serv. Corp., 104 S. Ct. 1464,1469 (1984)).

164. Copperweld, 104 S. Ct. at 2740.

165. Id. at 2741.

166. Id. at 2740.

167. Id. at 2741.

168. Id. at 2741-42.

169. Id. at 2742. 
structive. In modern times at least, sports leagues are not the product of a conspiratorial joining of barnstorming clubs. Rather, the league and its basic constituent clubs are born together. ${ }^{170}$ The simultaneous formation is essential, for the product being purveyed is not simply professional football, but rather a league race involving contests among clubs with competitive strengths that have been rendered roughly comparable by prior design. Typically, then, the option available to the marketplace is not league activity versus independent teams, but rather league activity versus having these same resources devoted to some nonfootball venture. Viewed in this light, the formation of the league is not a venture that has the net effect of depriving consumers of the benefit of independent centers of competition. ${ }^{171}$

It does not require a great deal of subtlety to see that once again the underlying issue is the extent to which it is desirable or efficient to demand interclub competition for franchise location. The problem witl the early intra-enterprise conspiracy cases was that they assumed that any increase in competition would be desirable, even if it occurred between two components irrevocably bound up in a common economic venture. Copperweld's reversal of the basic doctrine should serve to renew the point that not all justifications premised on supposed increases in the number of competitors will be persuasive. What is required is a more discerning analysis that considers the nature of the economic venture involved and allows integrated actors freedom to choose the manner in which they will compete.

\section{WHICH THEORY?}

An underlying theme of this article is that we must find an antitrust theory that more appropriately characterizes the franchising decisions of sports leagues. Under either of the alternative theories we have considered, Los Angeles Coliseum would be reversed, and the NFL would be permitted to prevent the Raiders from moving to Los Angeles. But the choice of the theory is hardly a matter of indifference. A variety of subsidiary issues turn upon the characterization that is given.

The forces favoring the use of a substantive, but favorable, section 1 rule of reason review are strong. Judicially created immunity in the anti-

170. The USFL is the most recent example, although the formation of other leagues in the past fifteen years-for example, the ABA, the WFL, and the WHA-follow the same pattern.

171. The precursor to the sports league was a haphazard collection of barnstorming clubsindependent centers of competition, if you will. By one account, the consequences of barnstorming were so unsatisfactory for both owners and fans that the formation of a league with centralized control-and restraints on competitive impulses-was an economic necessity. See Voight, The Boston Red Stockings: The Birth of Major League Baseball, 43 NEW ENG. Q. 531 (1970). 
trust area is not favored. Indeed, the Supreme Court has expended a good deal of energy in the last fifteen years striking down an array of real and supposed immunity grants that the courts had developed in earlier periods. ${ }^{172}$ The Court now frequently intimates that those who seek special dispensation should petition Congress. ${ }^{173}$

Another appeal of the rule of reason theory is that it allows for a case-by-case and issue-by-issue parceling of liability. Even if the franchise restrictions were allowed in the present case, the issue of league controls would never be placed beyond judicial scrutiny. ${ }^{174}$ Judicial oversight will continue, and where facts change or abuses are perceived, there remains a vehicle for a reassertion of public control. Finally, approval of the NFL's practice under the rule of reason does not represent a radical departure from the treatment of other unusual economic entities. The suggestion that executing a single entity-like function is enough to avoid section 1 is considerably less conventional. Formulators of judicial policy might be concerned that the unleashing of such a novel concept should be avoided where there is a plausible alternative. This more conservative approach avoids a potentially long stream of cases in which creative advocates try to show that the activities of their clients are entity-like and thus beyond section 1 scrutiny.

172. See, e.g., National Soc'y of Professional Eng'rs v. United States, 435 U.S. 679 (1978); Goldfarb v. Virginia State Bar, 421 U.S. 773 (1975); Comment, The Anatomy of Judicial Exemptions from Antitrust: A Study in Gap-Filling, 15 WAYNE L. REV. 813 (1969); see also Note, Antitrust Liability of Professional Associations After Goldfarb: Reformulating the Learned Professions' Exemption in the Lower Courts, 1977 Duke L.J. 1047.

173. See, e.g., National Soc'y of Professional Eng'rs v. United States, 435 U.S. 679, 689-90 (1978).

174. There is considerable disagreement, nevertheless, about how useful the rule of reason is as a device for achieving reliable, consistent results in sports antitrust cases. This is pointedly reflected in testimony given by various partisans in 1981-82 congressional hearings on the antitrust status of the NFL and other leagues. William R. Robertson, a commissioner of the Los Angeles Coliseum Commission, testified that "the rule of reason is designed precisely to permit judges and juries to mold antitrust standards to fit the particular circumstances of each case. . . The rule of reason is a highly flexible concept which provides the NFL with ample opportunity to justify its claimed right to extraordinary treatment." Hearings, supra note 8, at 370-71.

This contrasts with the view advanced by NFL Commissioner Pete Rozelle:

[E]ven when courts undertake to identify the league relationship and recognize its uniqueness, the courts have no standards for determining what the unique relationship means for antitrust analysis. The range of factors deemed relevant or irrelevant in the resulting analysis covers the entire spectrum and has been stated in contradictory fashion by different courts ....

$\cdots$

... [E]ach of the following factors has been dismissed as not being meaningful for purposes of "rule of reason" analysis: considerations of "fan loyalty," league "goodwill," league "stability," "common sense," "necessity" as an element of successful league operations, the entertainment qualities of the league's product, and playing field balance.

Id. at 216-17, 230-31. 
It appears to be correct that the rule of reason represents the softer landing in the present context. But such a choice holds a decided risk of subverting some critical considerations. In a general sense, these considerations touch on the question of how exacting a level of judicial oversight of league affairs should be encouraged. There is a case to be made that the league is entitled to operate with minimal controls under section 1 , at least insofar as its marketing policies are concerned.

An important premise of this view is the one developed at length earlier. ${ }^{175}$ In marketing its product, the league operates with many of the characteristics of an economically-integrated business. And despite some trappings of a collection of separate businesses, many of the internal incentives are the same as those found in business forms clearly outside the coverage of section 1 . The fact that the co-venturers have different net returns is not controlling, for the arrangement does not differ substantially from techniques used by integrated businesses to reward those who make unusual contributions to the success of the overall enterprise.

If we find that the league in fact functions with a high degree of integration, there is then reason to be concerned about the extent of judicial regulation that section 1 will impose. Copperweld indicates rather pointedly that the different treatment of integrated and collusive ventures under the antitrust laws is not the product of haphazard policy planning. ${ }^{176}$ There are desirable goals to be achieved by giving an integrated entity considerable latitude to determine how it will develop and market its product. Among other things, there is a potential for greater innovation and creativity than in a venture that is subjected to persistent judicial second-guessing. In addition, the role of the courts is placed in a more appropriate perspective. The judiciary will continue to be vigilant as far as market abuses are concerned. But the vehicle for oversight is the concern for improper monopolization. ${ }^{177}$ The primary goal of this type of enforcement is to insure that the competitive opportunities of outsiders are not improperly deterred. Avoided is the situation in which courts are called on to mediate what are essentially internal disputes about the distribution of the rewards of the entity's activity. Such cases are typified by a lack of substantial effect on the competitiveness of the relevant market, and a substantive diversion of the entity's attention away from its primary goals. The instant case may provide a significant example of the limited benefits that consumers will enjoy as a result of an

175. See supra notes $110-33$ and accompanying text.

176. See supra notes $162-69$ and accompanying text.

177. The potential relevance of section 2 of the Sherman Act is discussed supra notes $67-76$ and accompanying text. 
attempted judicial mediation of an internal entity dispute. 178

The courts' inclination to search for less restrictive alternatives under section 1 underscores the risk that an improper application of that section will stifle the operation of truly integrated firms. A premise of the concern for least restrictive restraints is that the rulemaker should operate with great care and precision in structuring its control. Under this approach, it is difficult to deal with situations that present unusual complexities or in which factual premises are highly uncertain. A later investigation may well reveal that there is a considerably less restrictive way in which the desired end could be achieved. The doctrine seems destined to favor caution over creativity and procedural elongation over quick adaptive behavior. Such a result is markedly at odds with the goal of encouraging flexibility and innovation.

Perhaps more to the point, there is little that is gained by this process of judicial accounting. When applied to nonintegrated actors, the admonition to draw restraints carefully has the effect of expanding the competitive opportunities of at least some participants. But as has been suggested, in the context of sports leagues, it is most doubtful that individual co-venturers will make a lasting contribution to general levels of competition. If the other participants within the league are allowed to pursue their legitimate interest in sharing and cooperation, these errant, selfish impulses will be contained by various techniques.

A final point is of a more intuitive nature. The rule of reason invites a type of inquiry that courts have had difficulty making accurately and efficiently in the sports industry. Very seldom is the economic complexity of the industry thoroughly understood. ${ }^{179}$ Nor have courts been par-

178. An earlier portion of this paper doubted whether the Los Angeles Coliseum decision will provide increased competition and expand consumer choice. See supra notes 55-56 and accompanying text.

Noticeably absent from the court's discussion is any gauge of the extent to which competition in the San Francisco-Oakland market was injured as a result of the league's inability to compel the Raiders to remain there. Indeed, when the Raiders' move from Oakland to Los Angeles is considered in connection with the Colts' move from Baltimore to Indianapolis, it is difficult to be confident that consumers benefited overall. Fans in at least two cities were significantly disappointed by these outcomes.

179. The district court in Mackey v. National Football League, 407 F. Supp. 1000 (D. Minn. 1975), aff'd in part \& remanded, 543 F.2d 606 (8th Cir. 1976), offers an example of the difficulties sometimes encountered in judicial appraisals of the economics of professional sports. Despite an extensive trial and a transcript of over 11,000 pages, the court concluded: (1) that "freedom of employment" of players would not affect the quality of play in the NFL; (2) even if "the quality of play would decrease," that fact would not justify a restraint on mobility; and (3) the NFL player restraints had not furthered competitive balance in the league. Id. at 1008. The court of appeals carefully avoided endorsing these statements and instead conceded the need for some type of equalization device. The court did disapprove the particular restraint before it as being overly broad. 543 F.2d at 621-22. As suggested elsewhere in this article, the need for equalization is now generally 
ticularly successful in explaining the seemingly contradictory incentives for intense athletic competition and pervasive economic cooperation. ${ }^{180}$ Nor has there been a truly serious effort to assess the extent to which the apparent individuality of clubs-both athletic and economic-is primarily a marketing device that masks a more basic spirit of cooperation. ${ }^{181}$ Certainly the Los Angeles Coliseum case leaves a long trail of uncertainty. Is the NFL really analogous to the Associated Press? Is it true that an NFL owner is free to reassign his players to a new USFL franchise? Is it true that there is no profit-sharing in the NFL television contract, gate receipt arrangement, and player allocation rules? In the face of massive revenue-sharing, can it seriously be maintained that individual club owners capture all rewards of astute managerial decisions?

The problem of dealing with limitations in the nature of the judicial institution is not unique to the sports industry. There are other settings in which the structure of traditional litigation and the unavailability of support personnel limit a court's understanding of the general context out of which a problem arises. ${ }^{182}$ Perhaps it is true that in most settings this situation should simply be accepted, or at least not shade the nature of substantive review. The present problem may be different, however. We are considering a choice between alternative theories that, if properly applied, should not produce wholly disparate results. Thus, we are assuming that the choice of a rule is not a choice between competing outcomes. In this context, it seems proper to consider the relative accuracy

accepted, see supra notes 17-18 and accompanying text, and there is no substantial disagreement that restraints on player mobility are an acceptable means of achieving this end. The fact that each of the unions representing players in the major professional leagues has consented to some type of restraint is instructive on this point.

180. A case that presents a particularly confused view of the nature of a sports league is Smith v. Pro Football, Inc., 593 F.2d 1173 (D.C. Cir. 1978). The court concludes that the special economic needs of the NFL allow it to avoid per se condemnation and calls for a rule of reason review. Id. at 1180. But the court then appears to refuse to consider these needs in making its substantive rule of reason analysis. The court finds that the need for playing strength balance on the athletic field is not procompetitive and should not be taken into account. Id. at 1186. In a later passage, however, the court seems to reverse itself yet again when it suggests that more mild versions of the draft would be acceptable under the rule of reason. Id. at 1188-89.

There is a growing body of opinion that the rule of reason analysis in that case is seriously flawed. See, e.g., Memorandum from Arnold \& Porter to Commissioner of Baseball Re: Problems That Would Arise in Applying the Rule of Reason to Baseball's Practices and Institutions (Feb. 22, 1982) reprinted in Hearings, supra note 8, at 439-45; Grauer, supra note 111, at 39-40; Robinson, Recent Developments-1979, 80 CoLUM. L. REv. 1, 21-22 (1980) ("there is something drastically wrong with a methodology that, after reviewing with painstaking care the purpose, history, and effect of a practice, ... totally ignores those reasons in deciding whether the self same practice constitutes an unreasonable restraint of trade").

181. See supra note 133 and accompanying text.

182. See, e.g., Horowitz, Decreeing Organizational Change: Judicial Supervision of Public Institutions, 1983 DUKE L.J. 1265, 1307. 
and efficiency of the decisionmaking process. Even accepting that the entity analogy has some imperfectly defined edges, its use would have the effect of forestalling a series of inquiries that have proven themselves to be diversionary in the past.

\section{CONCLUSION}

The process of scrutinizing the majority's single entity analysis and rethinking its rule of reason appraisal should serve to underscore a very basic criticism of Los Angeles Coliseum: the prospect for interclub competition that the court believes is the lynchpin of its analysis is wholly inadequate to support the broadscale reform that it seeks to launch. The vast majority of clubs in the NFL-or in any other league, for that matter-will never engage in serious economic competition. Moreover, the characteristics of club structure that the majority believes will provide the seeds for intraleague competition-separate managerial control and ultimate financial responsibility - may in fact be manifestations of something considerably different from fundamental independence. The residual authority of the league appears to be quite vast and may include a right to so restrict league relationships as to remove all opportunity and perhaps all incentives for separate action by individual clubs. A mandate for a complete pooling of revenues and expenses would produce that result. ${ }^{183}$

The majority uses the catchwords that would seem to bring its analysis in line with prevailing antitrust goals. It decries "monopoly prices;" it says it is striking a blow for increased competition; it alludes to the free market model of commercial behavior. At the same time, however, it embraces other notions that are more than mild qualifications on these premises. The concessions that the league has an interest in the financial stability of its constituent members and that competitive balance on the athletic field is important set up irreconcilable conflicts among the court's purported policy goals. It appears that the court would strongly prefer not to have to make a choice between the two competing concerns. Indeed, in the majority's opinion the tension that results from the meeting of these two forces is never expressly resolved, nor even addressed. The notions of the desirability of internal competition and the league's interest in financial equalization are kept well apart.

The alternative perspective proposed here is one that gives more credence to the corporate nature of the league venture. Valuable franchise locations hardly resemble open-market opportunities to be plucked by the first available entrepreneur. Many entities, including

183. See supra notes 123-24 and accompanying text. 
clubs located in distant cities, have contributed to the value of these opportunities. It seems quite natural that those who create the important asset should have the right to share in the fruits of this collective effort. Even individual athletic contests between two clubs have strong corporate overtones. The majority seems clearly wrong in suggesting that each individual club offers a separate product. A club playing itself is not very exciting. Nor is there much excitement in that same club playing a random group of opponents of uncertain and uneven quality. Of a clearly different magnitude is the athletic encounter between clubs whose talents have meaning for some larger purpose beyond the immediate outcome. But it is, of course, the league - the corporate entity - that provides the occasion for that larger significance, and it is the league's nurturing that has produced the fans' relative preference for this league's product over other competing versions. More pointedly, USFL football is not NFL football, and games involving a team called the Raiders are not equally exciting in each league.

The preference expressed in this piece is one that encourages corporate innovation at the level of the most relevant entity. The periodic judgments that need to be made about how best to shape and promote the NFL product are not of a sort amenable to the objectification called for by the court's approach. There will, however, still be a need for continued judicial oversight. The tendencies toward monopolization are unmistakable in the various professional sports. But these concerns for innovation and oversight can be accommodated. Other provisions of the antitrust laws suggest such a vehicle. In the alternative regime envisaged here, internal divisiveness will be discouraged, or at least not encouraged. There will, nevertheless, be an antitrust accounting, but one that looks at ends rather than means. 